Article

\title{
Forest Landscape Restoration-What Generates Failure and Success?
}

\author{
Markus Höhl ${ }^{1,2, * \mathbb{D}}$, Vianny Ahimbisibwe ${ }^{3} \mathbb{D}$, John A. Stanturf ${ }^{4} \mathbb{D}$, Peter Elsasser $^{3} \mathbb{D}_{\text {, }}$ \\ Michael Kleine ${ }^{5}$ and Andreas Bolte ${ }^{2}$ D \\ 1 Graduate School Forest and Agricultural Sciences (GFA), University of Göttingen, Büsgenweg 5, \\ 37077 Göttingen, Germany \\ 2 Thünen Institute of Forest Ecosystems, Alfred-Moeller-Straße 1, 16225 Eberswalde, Germany; \\ andreas.bolte@thuenen.de \\ 3 Thünen Institute of International Forestry and Forest Economics, Leuschnerstraße 91, 21031 Hamburg, \\ Germany; vianny.ahimbisibwe@thuenen.de (V.A.); peter.elsasser@thuenen.de (P.E.) \\ 4 Institute of Forestry and Rural Engineering, Estonian University of Life Sciences, Kreutzwaldi 5, \\ 51014 Tartu, Estonia; drdirt48@gmail.com \\ 5 IUFRO, Marxergasse 2, 1030 Vienna, Austria; kleine@iufro.org \\ * Correspondence: markus.hoehl@thuenen.de
}

Received: 28 July 2020; Accepted: 24 August 2020; Published: 27 August 2020

\begin{abstract}
Research Highlights: The global Forest Landscape Restoration ambitions could be impaired by projects that ignore key principles such as the engagement of local communities in decision making and implementation, equitable benefit sharing, and monitoring for adaptive management. This entails the danger of continued degradation, disappointed local stakeholders, and ultimately, project failure. Other projects face technical problems related to tree establishment and nursery production. Background and Objectives: There are high hopes for Forest and Landscape Restoration to regain ecosystem integrity and enhance human well-being in deforested and degraded areas. We highlight various problems and success factors experienced during project implementation on a global scale. Materials and Methods: We use data from a global online survey to identify common obstacles and success factors for the implementation of forest restoration. Results: While the majority of respondents reported successful projects, others indicate drastic problems and failed projects. Major obstacles to forest restoration experienced by survey respondents were a lack of local stakeholder involvement and a mismatch between goals of local communities and restoration managers, as well as environmental, anthropogenic, and technical barriers to tree regeneration. Conclusions: When local communities, their goals, and needs are disregarded in project planning and implementation, as reported from various cases in our survey and the limited available literature, there is a risk of project failure. Failed projects and disappointed stakeholders, as well as discouraged funders and policy-makers, could lessen the momentum of global forest restoration ambitions. Adhering to key principles of Forest and Landscape Restoration can promote much-needed community support, with the potential to overcome barriers to forest regeneration and enable communities for the protection, management, and monitoring of the restored forests beyond the limited project and funding periods. Research is needed to gain a better understanding of the perception of local communities towards restoration activities. Further studies on the implementation of forest restoration at the intersection of environmental factors, socioeconomic conditions, forest regeneration/silviculture, and nursery production are needed.
\end{abstract}

Keywords: forest and landscape restoration; forest restoration problems; forest restoration success; community participation; forest regeneration; nursery production 


\section{Introduction}

Forest and Landscape Restoration (FLR) has attracted global attention with the recent declaration of the UN Decade on Ecosystem Restoration [1] and the Bonn Challenge/New York Declaration on Forests aiming to bring 350 million hectares of deforested and degraded land into restoration by 2030 [2]. Likewise, the Convention on Biological Diversity (CBD) calls for the restoration of $15 \%$ of the degraded ecosystems and the associated ecosystem services, as stated in Aichi Target No. 14 and 15 [3]. However, the translation of these ambitious goals into reality is a major challenge. Successful restoration efforts must consider the complexity and changing nature of ecosystems and site conditions [4], diverse and sometimes unstable sociopolitical systems and stakeholder needs [5], difficult economic and legal situations [6], continued deforestation and forest degradation, and limited technical capacities [7].

The resulting need for practical guidance is being addressed by a variety of tools and guidelines in support of FLR. A comprehensive overview and description of the available decision support tools in the context of FLR was published recently [8]. The review identifies a lack of tools that go beyond assessments of restoration opportunities at broader scales (e.g., the country level) and aid decision-making for FLR implementation [8], although there has been some effort to address this $[9,10]$. Apart from implementation-focused decision support tools, there is a need for the exchange of practical experience in FLR implementation to improve restoration practice [11,12]. More specifically, the CBD Decision No. 16 from the 11th Conference of the Parties calls for knowledge transfer, as well as the compilation and dissemination of case studies, best practices, lessons learned, and methods for assessing the success of restoration projects [13]. Yet, practical experience with successful, as well as failed, restoration projects has only been sparsely published [14]. While promising FLR success stories are being prominently showcased [11,15-20], many restoration projects fail to meet their expectations [21]. Success stories can provide lessons for future restoration projects and can undoubtedly be necessary to convince potential FLR investors or policy-makers [22]. However, restoration failures might be more common than success stories but are rarely being communicated, resulting in a positive reporting bias $[14,21]$. Therefore, specific problems that arose during FLR implementation should be considered to learn from setbacks experienced by other restoration practitioners and improve restoration practices or avoid common mistakes.

Against this background, it is our goal to share practical experiences in forest restoration among the FLR community and beyond. To this end, we summarize the information provided in a global online survey on experiences with forest restoration and adaptation, following the Adaptive Measures concept that integrates adaptive forest management (AFM) and FLR at different spatial scales [23]. For the survey and this publication, we define AFM as a set of stand-related management concepts and measures that are targeted to adapt existing forest stands to changing environmental conditions, e.g., due to climate change or changing societal demands. On the other hand, Forest and Landscape Restoration (FLR) comprises measures at the landscape scale that are targeted to restore degraded or deforested landscapes, with a focus to restore forest functions. We present challenges and possible success factors experienced during project implementations in various parts of the world, with a focus on forest restoration activities. This article describes the general results obtained in the survey and highlights particular problems and possible responses that were described by the respondents. The identified issues are then discussed with respect to the related literature to provide a current overview of the global challenges and facilitating factors experienced during the practical implementations of forest restoration. Published tools to overcome common restoration obstacles are presented to provide a solution-oriented reference for forestry experts and practitioners. We will emphasize pitfalls and setbacks reported by survey respondents in response to the prevalent positive reporting bias described above.

The novelty of this approach is to summarize mostly unpublished information on restoration implementations on a global scale and focus on setbacks and problems instead of publishing yet another FLR success story.

We will answer the following research questions: What are common problems and success factors for FLR implementation reported by survey respondents from different parts of the world? 
Have similar problems been described in the literature, and what are potential solutions to address the identified issues?

We found that crucial principles of FLR that were developed by the Global Partnership on Forest and Landscape Restoration [11] have been ignored in several projects reported in our survey, as well as the published literature. Disregarding the needs of local communities and their participation in decision-making and project implementations resulted in a lack of much-needed community support and continued degradation, threatening restoration success. Local communities can play a key role in restoration implementation-in particular, with ongoing activities such as tending, site protection, and monitoring. Therefore, local stakeholder engagement should be seen as an opportunity for the projects rather than a difficulty. Other obstacles identified by the survey relate to environmental and technical difficulties of tree regeneration, particularly in harsh environmental conditions and for a limited supply of high-quality native seedlings.

\section{Materials and Methods}

The survey compiled global experience and knowledge from forestry experts and practitioners (see Figure 1 for sample compositions) concerning real-world examples of AFM and FLR. The survey text was translated into 12 different languages (English, Chinese, French, German, Indonesian, Italian, Japanese, Polish, Portuguese, Russian, Serbian, Spanish, and Turkish) by native-speaking experts to reach stakeholders in their mother tongues. Then, it was disseminated using the extended network of the IUFRO Task Force on Forest Adaptation and Restoration under Global Change (by e-mail), IUFRO Division and Task Force mailing lists, IUFRO Twitter and Facebook accounts, and by promotion at related scientific conferences. As the intention of the survey was qualitative, i.e., to collect as much relevant information as possible (rather than returning a representative picture of all existing AFM and FLR projects), we applied a snowball sampling approach. We asked the addressees mentioned above to distribute the survey further in their respective networks. It should be kept in mind that the collected data may not be representative of all FLR and AFM projects that exist globally.

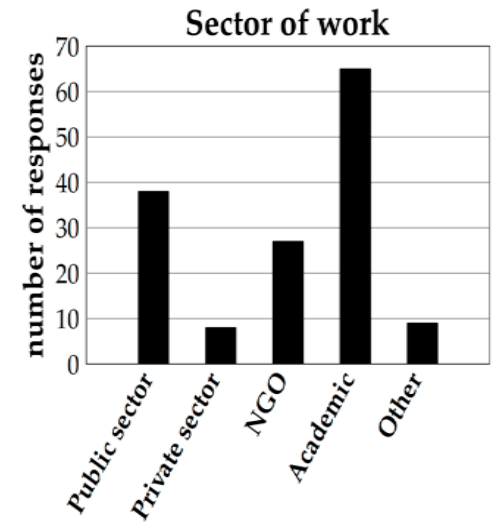

(a)

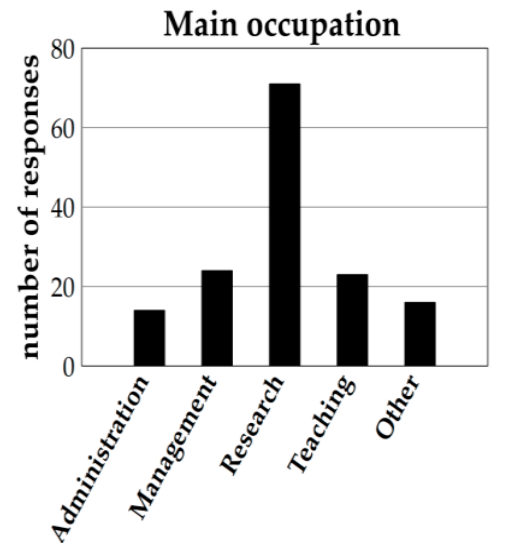

(b)

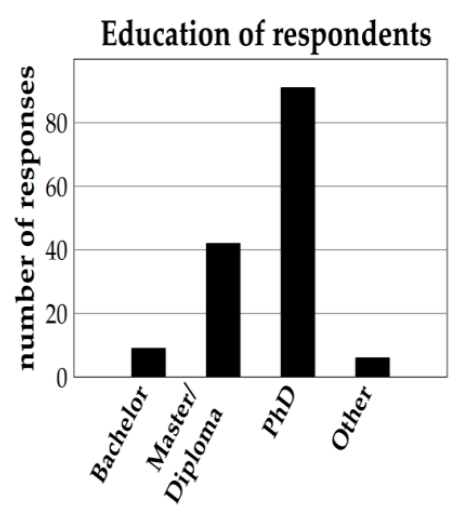

(c)

Figure 1. Sample composition-(a) sector of work, (b) main occupation, and (c) level of education of survey respondents.NGO abbreviates Non-governmental organization.

The survey consisted of an introductory page describing the purpose, concepts, and content of the survey, followed by three thematic sections. Section I contained 19 questions about the forest(s) and landscape(s) reported by the respondents, their location, initial condition, the applied measures, the environmental conditions, the current and former management regimes, forest ownership, and other entities relevant for management decisions (i.e., stakeholders). Section II contained two series of questions where respondents were asked to assess, on 5-point Likert scales, which goals they considered to be important for the initiation of applied measures and how successful these interventions have been according to their perceptions. Each of the question series was followed by an open question for further 
comments. Section III concluded the survey with six questions about the personal characteristics of the respondents and their professions. The survey questions are included as Supplementary Materials.

At the time of writing, a total of 166 responses (146 full and 20 partial) were collected from 66 different countries distributed globally (Table 1 and Figure 2). Responses to the survey were submitted between February 2017 and August 2019. About 25\% of the reported projects were classified as $\operatorname{AFM}(n=42), 32 \%$ as FLR $(n=52)$, and $42 \%$ as approaches that integrated AFM and FLR $(n=69)$, from this point onwards referred to as combined approaches. As the focus of this publication is on FLR, we will mainly present results obtained from responses for FLR and combined approaches. Survey participants were asked to indicate until what year the former land-use was in place before measures to restore or adapt forests were implemented. Most respondents reported that the former land-use was changed at some point between 1990 and 2019. Several projects reported that the former (often degrading) land-use was abandoned during the 20th century, dating back as long as 1900-in particular, in Europe, where agricultural land-uses were excluded from forests.

Table 1. Number of respondents by project country and continent.

\begin{tabular}{cccccccc}
\hline Africa & $\mathbf{n}$ & Asia + Oceania & $\mathbf{n}$ & Europe & $\mathbf{n}$ & Americas & $\mathbf{n}$ \\
\hline Angola & 1 & Bangladesh & 1 & Austria & 5 & S-/C-America \\
Burkina Faso & 2 & Bhutan & 1 & Croatia & 1 & Bolivia & 1 \\
Cameroon & 1 & China & 7 & France & 2 & Brazil & 5 \\
Ethiopia & 5 & India & 6 & Germany & 13 & Chile & 3 \\
Ghana & 3 & Indonesia & 2 & Iceland & 5 & Colombia & 3 \\
Kenya & 4 & Iran & 3 & Italy & 6 & Costa Rica & 4 \\
Malawi & 2 & Japan & 3 & Netherlands & 1 & Ecuador & 2 \\
Mali & 1 & Kyrgyzstan & 1 & Poland & 3 & Guatemala & 1 \\
Mozambique & 1 & Laos & 1 & Portugal & 2 & México & 1 \\
Niger & 2 & Laos, Vietnam, Thailand & 1 & Russian Fed. & 4 & Peru & 2 \\
Nigeria & 3 & Malaysia & 1 & Scotland & 1 & Puerto Rico & 1 \\
Rep. o. t. Congo & 1 & Mongolia & 1 & Serbia & 5 & Venezuela & 2 \\
Senegal & 1 & Myanmar & 1 & Slovenia & 1 & & N-America \\
South Africa & 1 & Nepal & 1 & Spain & 4 & Canada & 6 \\
Tanzania & 3 & Pakistan & 1 & Sweden & 2 & USA & 4 \\
Uganda & 2 & Philippines & 3 & Ukraine & 1 & & \\
& Thailand & 2 & UK & 3 & &
\end{tabular}

The lack of representativeness of the survey dataset that results from our sampling approach calls for a purely qualitative analysis of the survey results. We, therefore, use descriptive statistics for the multiple-choice and ranking questions. Additional information from open text answers ("other" option in multiple-choice questions) and comment fields were categorized according to the topics that were addressed by the respondents. Whenever we refer to specific responses, we cite them by using their respondent ID to enable readers to access the response information from the Supplemental Materials. Literal qutoes from survey responses as well as published literature are indicated using italics. We created a subset containing 67 responses that provided comments with additional information related to success, failure, problems, and solutions during project implementations. The subset consisted of nine AFM cases, 33 FLR cases, and 25 cases applying combined approaches. The categories for these responses, many of which were interrelated, were then grouped into three broader topics that will be addressed in this publication: restoration goals and success, local communities in FLR, and forest regeneration. Table 2 gives an overview of the different categories of comments and the broader topics they were assigned to. The number of respondents that provided information for each of the categories concerning project success, failure, problems, and solutions is indicated in square brackets. The topics provide the structure for the results and discussion of this publication. In addition to the information provided by the respondents, we reviewed the related literature to ascertain whether similar observations were made by other researchers. The literature review also enabled us to provide a 
summary of available tools to overcome common restoration barriers in the discussion. This overview serves as a reference for forestry experts and practitioners that are confronted with similar obstacles.

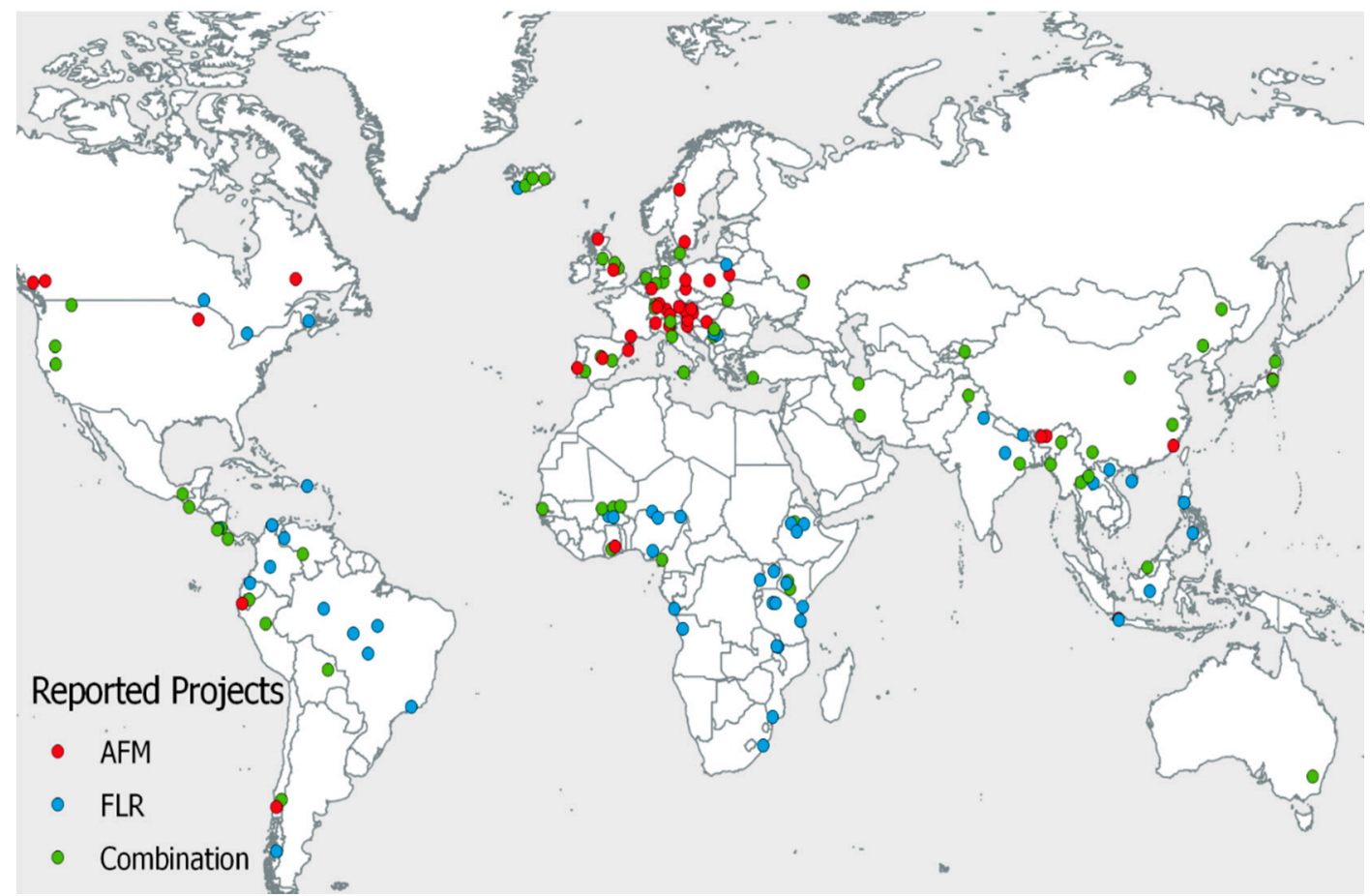

Figure 2. Distribution of projects reported in the survey by type of project. AFM: adaptive forest management and FLR: Forest and Landscape Restoration.

Table 2. Topics addressed were concerning project success and failure and encountered problems and solutions, with corresponding categories assigned to responses and their number of occurrences in the survey data, as indicated in square brackets. The associated sections of this publication are indicated in parentheses behind the respective topics. AFM: adaptive forest management and FLR: Forest and Landscape Restoration.

\begin{tabular}{|c|c|c|}
\hline $\begin{array}{c}\text { Restoration Goals and Success } \\
\text { (Section 3.1) }\end{array}$ & $\begin{array}{l}\text { Forest Regeneration } \\
\quad \text { (Section 3.2) }\end{array}$ & $\begin{array}{l}\text { Local Communities in FLR } \\
\text { (Section 3.3) }\end{array}$ \\
\hline $\begin{array}{l}\text { conflicting goals (Section 3.1.1) } \\
{[n=22 \text {; AFM: 9, FLR: } 6,} \\
\text { combination: 7] }\end{array}$ & $\begin{array}{l}\text { natural regeneration (Section 3.2.1) } \\
\text { [n=7; FLR: 6, combination: 8] }\end{array}$ & $\begin{array}{l}\text { stakeholder and community } \\
\text { involvement (Section 3.3.1) } \\
\text { [n= 20; AFM: 1, FLR: } 14 \\
\text { combination: } 5]\end{array}$ \\
\hline $\begin{array}{c}\text { measuring progress (Section 3.1.2) } \\
\text { [ } n=7 \text {, AFM: } 1 \text {, FLR: } 3 \\
\text { combination: } 3]\end{array}$ & $\begin{array}{l}\text { natural regeneration constraints } \\
\text { (Section 3.2.1) } \\
\text { [ } n=9 ; \text { AFM: 3, FLR: } 4 \\
\text { combination: } 2]\end{array}$ & $\begin{array}{l}\text { perceived benefits for land-users } \\
\text { (Section 3.3.2) } \\
\text { [n=9; FLR: 7, combination: 2] }\end{array}$ \\
\hline $\begin{array}{l}\text { project and funding duration } \\
\text { (Section 3.1.2) } \\
\text { [n=4; FLR: 2, combination: 2] }\end{array}$ & $\begin{array}{l}\text { assisting natural regeneration } \\
\text { (Section 3.2.2) } \\
{[n=8 ; \text { AFM: } 2, \text { FLR: } 3} \\
\text { combination: } 3]\end{array}$ & $\begin{array}{l}\text { continued degradation } \\
\quad \text { (Section 3.3.3) } \\
{[n=9 ; \text { AFM: } 1, \text { FLR: } 4} \\
\text { combination: } 4]\end{array}$ \\
\hline $\begin{array}{l}\text { adapting rest. measures/goals } \\
\text { (Section 3.1.3) } \\
\text { [n=6; FLR: 5, combination: 1] }\end{array}$ & $\begin{array}{l}\text { active regeneration/planting } \\
\text { (Section 3.2.3) } \\
{[n=15 ; \text { FLR: 7, combination: } 8]}\end{array}$ & $\begin{array}{c}\text { institutional and technical } \\
\text { challenges (Section 3.3.4) } \\
\text { [n=5; FLR: 3, combination: 2] }\end{array}$ \\
\hline $\begin{array}{l}\text { socioeconomic change } \\
\text { (Section 3.1.3) } \\
\text { [n=4; FLR: } 4]\end{array}$ & $\begin{array}{c}\text { Seedling quality and supply } \\
\text { (Section 3.2.4) } \\
\text { [n=6; FLR: 4, combination: 2] } \\
\text { tree species selection (Section 3.2.4) } \\
\text { [n = 7; FLR: 5, combination: } 2]\end{array}$ & $\begin{array}{l}\text { tenure issues (Section 3.3.4) } \\
\text { [n=2; FLR: 2] }\end{array}$ \\
\hline
\end{tabular}




\section{Results}

\subsection{Restoration Goals and Success}

Survey respondents were asked to rate the priority of broad management goals for the project (Figure 3). Apparent is that each of the listed goals is relevant for certain projects. The protection function, water issues, nature and biodiversity conservation, forest productivity, and income generation are particularly important. Other priorities mentioned by respondents were: changes in forest structure; genetic variability of tree species; increased resilience of forests; specific ecosystem services (wildlife habitat and management, fire resistance, amenity, recreation, and carbon sequestration); and socioeconomic goals such as rural development and the provision of necessities such as water and food. On average, respondents selected more than four different priorities for the initiation of the restoration measures. About $75 \%$ of the respondents reported priorities that are related to both conservation and productivity/income goals.

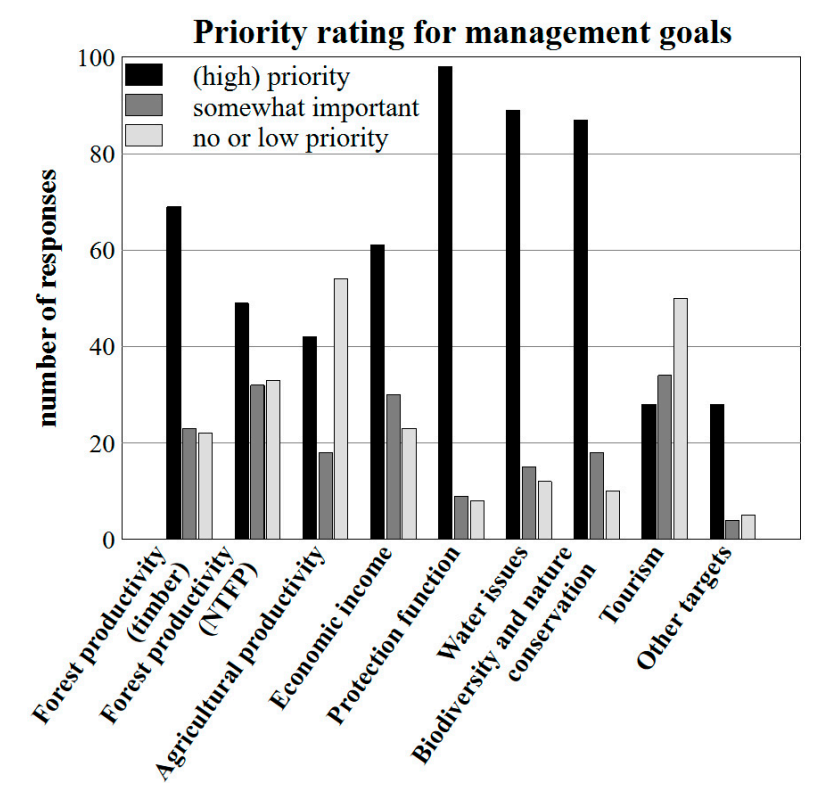

Figure 3. Management targets by different priorities reported in the survey for FLR and combined approaches. NTFP abbreviates Non-timber forest products.

Subsequently, the respondents were asked if the implemented measures were successful in reaching the selected goals. Figure 4 shows that most respondents perceive the implemented measures to be successful. Only 20 respondents reported that management goals were not met, and in another 21 cases, the applied measures were only partially successful. Partial success or failure was mainly reported for projects applying FLR or combined approaches (Figure 4). This is, of course, a subjective reflection of restoration success by the survey respondents, and for FLR and combined projects, several respondents reported differing stakeholder perceptions of project success (Figure 5). 


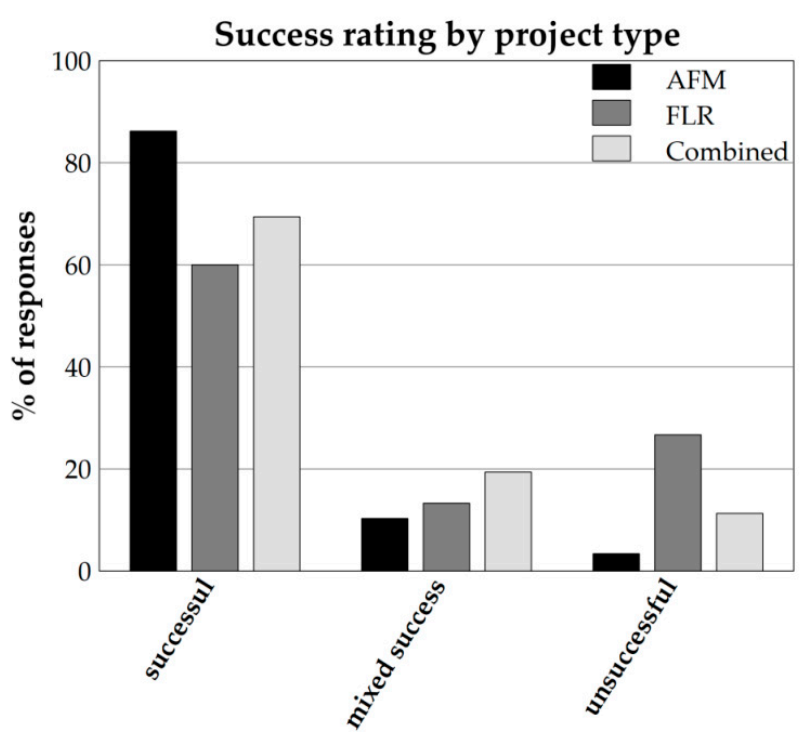

Figure 4. Ratings of project success by project type. Successful projects are defined as those where the respondents strongly agreed or mostly agreed that the implemented measures were successful in reaching the selected goals. Mixed success includes responses that partly agreed/disagreed with the mentioned statement. Unsuccessful cases are defined as those responses that mostly disagreed or strongly disagreed with the before-mentioned statement.

\section{Perception of success}

Level of agreement: "All local stakeholders

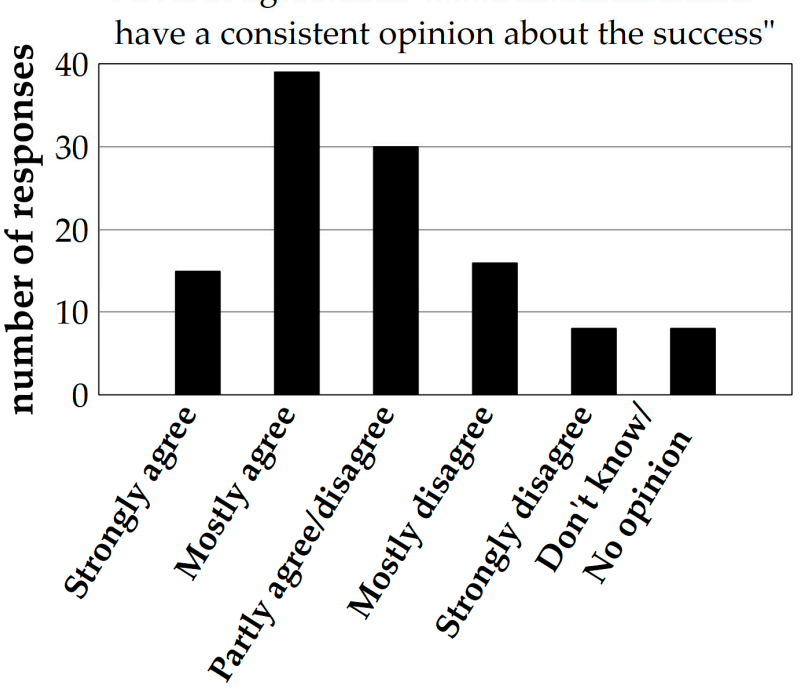

Figure 5. Perceptions of different stakeholders about successes for FLR and combined projects.

In comparison to seemingly problem-free projects, respondents provided more details for less successful projects, often describing perceived causes of failure in the comment fields. Alongside the success factors that were mentioned in the comments by several respondents, the described problems were grouped into the following topics: conflicting goals, measuring progress/success and project and funding duration, adapting restoration measures, and goals and socioeconomic changes. The following paragraphs describe the reported problems and success factors for each topic.

\subsubsection{Conflicting Goals}

Conflicting goals of the different stakeholder groups were described by 21 respondents (Table 2). For AFM and combined projects in Europe, this was mainly limited to trade-offs between economic, production, and carbon sequestration goals on the one hand and the changing tree species composition 
for adaptation and nature conservation goals on the other (IDs: 465, 209, 240, 385, 441, 534, 645, 737, and 900). Yet, in FLR and combined projects in other parts of the world, such conflicting goals were described to cause major problems or even project failure.

In an NGO-led assisted natural regeneration (ANR) project reported for the Mzuzu region in Northern Malawi (ID 529), the regeneration of native species on degraded former pine plantations by fencing and fire suppression failed. The respondent described a situation where aggressive weeds and the breaking of fences with subsequent grazing and fire during the dry season prevented successful natural regeneration. The encroachment into the restoration plots was associated with local people perceiving the plots as being unused. The respondent further stated: "We learned that the reestablishment of forest through natural regeneration is no sufficient goal and project goals need to be clearly communicated to, and understood by, local communities. We expect better outcomes of future activities when goals are clearly defined and well known by the local population." Besides this lack of communication, it appears that the local land-users were also not consulted when the goals were defined and had different goals regarding the land-use of the restoration area.

From the Andes of Southern Ecuador, a project was reported where native trees were planted on degraded land owned and managed by local communities. Priorities of the university-led and NGO-funded initiative were the provision (Non-timber forest products (NTFPs) and agriculture) and protection functions (water and erosion) (ID: 246). The project was rated to be unsuccessful, and it was stated that local stakeholders were not willing to invest time and other resources in managing/recovering degraded areas. It appears that the local community was not sufficiently motivated by the goals pursued by the university, which led to project failure.

In two cases from Nigeria, it was observed that planted non-fruit-bearing tree species were cut down for fuelwood (ID: 599) or not nurtured by local communities, while fruiting species survived, as they were fostered (ID: 691). Thus, the goals of these projects (i.e., fighting desertification) did not meet the goals of the local community, which were more production-oriented (fuelwood and fruits). A similar situation was also described for the Ruvu region in Tanzania, where charcoal production and logging were banned by the law against the will of the local communities. Here, the acceptance for restoration and conservation of the forests was gained over time with improved livelihoods (ID: 667).

One respondent from Brazil described a situation in the Atlantic Forest where the forest code requires land-users to restore deforested slopes. Yet, most land-users do not comply with the law, as their monetary means are limited, and future timber production in the restored areas is not an option, indicating a conflict between conservation and production goals (ID: 524).

A respondent from China criticized that the ambitious afforestation goals with the focus on plantations of non-native species led to a replacement of natural forests and grasslands, referring to the published literature [24,25]. The respondent states that this jeopardized conservation goals on Hainan Island and in Shaanxi Province. In the latter, it even increased wind erosion in arid natural grasslands, although erosion control and sandstorm reduction were intended by the afforestation project (IDs: 797 and 798). Another respondent from China describes a lack of livelihood alternatives resulting in deforestation for crop tree cultivations by local inhabitants of Hainan Island, also indicating that the restoration goals were not met (ID: 935).

The mentioned cases indicate a lack of consideration of the various goals of the involved stakeholder groups. The described projects can serve as examples indicating that disregarding the goals of the local land-users as key stakeholders can lead to situations where project goals are not reached.

\subsubsection{Measuring Progress/Success and Project/Funding Duration}

Measuring the progress towards goals or project success was identified as a challenge by seven respondents (Table 2). The need for a longer timeframe to judge restoration success (IDs 147 and 534); technical challenges in the monitoring of socioeconomic indicators (ID: 166); insufficient or nonexistent monitoring activities (IDs 549, 671, and 897); and narrowly defined goals and indicators (ID: 797) were mentioned in this context. 
As an example, one respondent stated that many forest plantations in Western Kenya with the goals to recultivate barren lands, create jobs, and induce rural development often lacked monitoring of the plantation developments. This was linked to problems regarding the adaptation of management strategies, insufficient thinning, and omitted the harvest at the time of highest return on the investment (ID: 671).

In the already mentioned example from Hainan Island in China, it was criticized that success was only measured based on forest area increase, while ignoring the ecological impact of the afforestation measures (ID: 797).

In addition to this, several respondents also addressed the short durations of restoration projects and funding, which limits project capacities for follow-up activities and adaptive management (ID: 166, 549,794 , and 805).

\subsubsection{Adapting Restoration Measures and Goals and Socioeconomic Changes}

Six respondents (Table 2) described situations where the initial project goals and measures had to be adapted due to unforeseen problems during implementations.

A project from Northwest Vietnam with the main goal to reduce erosion and secure agricultural productivity failed to realize the initial nature conservation goals due to a limited supply of native seedlings. The species selection had to be adapted, and pines were planted to meet the soil protection goals during the limited project timeframe. According to the respondent, local farmers perceived the positive effects of soil protection, and seedlings of native trees were present in the pine stands after only five years of establishment (ID: 794).

A similar case was reported from the Bengo region of Angola, where the initial production goals had to be abandoned due to a lack of native seedlings. Focusing on erosion control goals by using the available exotic trees as a riparian buffer resulted in partial project success (ID: 387).

In a case from Colombia, where the quality and quantity of native seedlings were insufficient, unplanted areas and low seedling survival was reported. The respondent stated that adapting to these project shortcomings was not possible due to the limited project duration (ID: 805).

In a project from Senegal, the planted forests did not meet their expectations in terms of fuelwood provision, as the plantations were less productive than expected. Other restoration goals like the protection from sandstorms and fodder for livestock were achieved, as the trees were not harvested for fuelwood (ID: 730). From Kenya and the Republic of the Congo (RotC), two examples of economic failure of forest plantations due to declining pulp prices were reported. In both cases, the initial economic goals were abandoned, while the plantations' provisioning services became important for the local populations due to fuelwood production, job creation, and rural development (Kenya, ID: 671) and the prevention of deforestation of natural forests through the provision of fuelwood (RotC, ID: 892). It was mentioned that the plantation managements need to be adapted to suit the current roles for timber and fuel productions for local markets, the facilitation of natural regeneration, and wildlife habitats (ID:671).

In other situations, forest restoration was not a goal but an unintended byproduct of socioeconomic changes, leading to the abandonment of agricultural practices, as reported for cases from Puerto Rico (ID: 828) and Costa Rica (ID: 595). As noted by the respondents, these examples of spontaneous and passive forest restorations are described in detail in the literature [26,27].

\subsection{Forest Regeneration}

Issues that are related to forest regeneration have been reported for all types of projects and various forms of regeneration. They form the second thematic group for this publication (Table 2). Several conditions that have limited regeneration success were described by the respondents (Table 3). These conditions and possible solutions proposed by our respondents and the related literature are presented in the following sections. Regarding the tree species selection, we found that local 
provenances of native species were promoted in most projects, while exotic species or nonlocal provenances were rarely used exclusively and were mostly an addition to native tree species (Figure 6).

Table 3. Obstacles to forest/tree regeneration reported by respondents.

\begin{tabular}{cl}
\hline & High levels of degradation prevent natural regeneration and successful plantings: \\
& low germination, survival, and pollination rates due to soil degradation, harsh \\
environmental conditions, lack of pollinators, and propagules (IDs: 145, 151, 394, & \\
Properties of the & $825,798,860$, and 599). \\
Biophysical & Presence and dominance of aggressive weeds or other competing vegetations \\
Environment & inhibitnatural regeneration (IDs: 849, 529, 755, and 857). \\
& Browsing by wildlife prevents regeneration success (IDs: 575, 900, and 696). \\
& Fire threatens regeneration (IDs: 394, 529, 558, and 862). \\
\hline \multirow{2}{*}{ Human pressures } & Degrading activities persist on or recur to restoration sites and prevent the \\
& success of both natural regeneration, as well as plantings: grazing (IDs: 529); fire \\
& (IDs: 529 and 558); fuelwood collection (IDs: 599, 691, and 751); and shifting \\
& cultivations or other agricultural uses (IDs: 751). \\
\hline \multirow{3}{*}{ Technical issues } & Insufficient seedling supply from nurseries (IDs: 387, 897, 805, and 794). \\
& Seedling quality is low, or seedlings are not adapted to the site, or wrong species \\
& were planted (IDs: 897 and 599). \\
& Insufficient irrigation and tending activities (IDs: 860, 599, and 857). \\
\hline
\end{tabular}

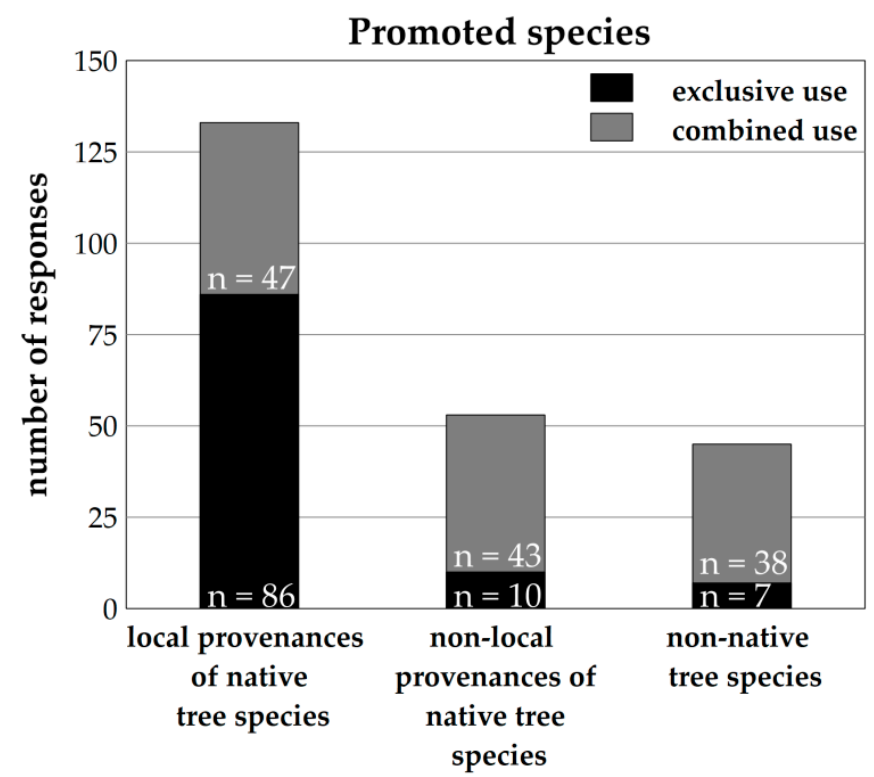

Figure 6. Species promoted in the respective projects-black bars: the respondents reported the exclusive use of the particular type of species, and grey bars: the respondents reported using the particular species type in combination with other species types.

\subsubsection{Natural Regeneration and Its Constraints}

Spontaneous natural regeneration has the potential to recover forests without further interventions under suitable biophysical and socioeconomic conditions, as reported by two respondents. These cases of spontaneous natural regeneration due to socioeconomic changes and concomitant abandonment of agricultural areas from Costa Rica and Puerto Rico were reported with reference to related publications (IDs: 595 and 828) [26-28]. However, natural regeneration can be inhibited by various environmental constraints and human pressures - in particular, high levels of degradation or harsh environmental conditions, the dominance of aggressive weeds, browsing damage, fire, and continued or recurring degradation were reported by various respondents (Table 3). Moreover, relying on natural regeneration can limit the economic performance of the forest stands (ID: 465). 


\subsubsection{Assisted Natural Regeneration (ANR)}

Respondents described various interventions to overcome barriers to natural regeneration that can be classified as ANR. To counter browsing damage, respondents proposed changes in hunting activities (IDs: 575, 696, and 900) or fencing and single tree protection (ID: 529, 755, and 900). Fire management practices are proposed or implemented in fire-prone areas (ID: 529, 589, and 693). Site preparation can be necessary where aggressive weeds prevent natural regeneration (ID: 849). ANR can also include changes in land-use practices, as reported by several cases that include measures such as avoiding slash and burn practices of regenerating forest areas (ID: 166), changing the silvicultural system and avoiding grazing (ID: 151), the application of thinning and enrichment planting (ID: 862), the restriction of the use of fire and NTFP collections (ID: 693), fire suppression at the expense of pasture productivity (ID: 589), or the restriction of access and any human intervention (ID: 705). However, some projects failed to achieve such changes, as exemplified by the mentioned intrusion into ANR plots in Malawi (ID: 529) or the continued encroachment of protected forest areas for agricultural use in Cameroon (ID: 751). Cases of successful farmer-managed natural regeneration, including protection from livestock (ID: 833 and 808), as well as communal forest protection from various drivers of degradation (ID: 693), demonstrate the value of community participation in ANR. Cases in which barriers to regeneration success were only partially anticipated (fences and firebreaks), while others were not (competition from weeds (ID: 529 and 755 and recurring human pressures (ID: 529 and 751)), have failed to successfully regenerate trees.

\subsubsection{Active Restoration at the Limits of Natural Regeneration}

Survey respondents reported active restoration approaches under unfavorable environmental conditions: Mining sites were actively replanted using native (IDs: 760, 145) and non-native (IDs: 760 and 825), and nitrogen-fixing tree species (ID: 760 and 825). In projects from Germany and China, it was necessary to plant early successional species after disturbances to re-establish tree shelters and facilitate suitable growth conditions for the target tree species (IDs: 200 and 673). Where trees were needed to combat desertification under very harsh environmental conditions, respondents regularly reported active tree-planting approaches in (semi-)arid regions of Nigeria, Mali, Burkina Faso, The Niger, Senegal, and China (IDs: 599, 691, 668, 669, 670, 730, and 798).

While active forest regeneration approaches have been perceived as an option in areas where passive restoration is constrained by environmental conditions, several respondents reported that active approaches are not immune to regeneration failure. For instance, forest reestablishment projects in arid regions of China, as well as the tropical Philippines and subtropical Colombia, faced low survival rates, because the trees were not adapted to the site conditions (IDs: 798, 897, and 805). Tree plantings in Nigeria were also associated with high failure rates due to the low adaptation of seedlings to drought but also because of a lack of commitment and resources of local communities for irrigation (ID: 860, 599, and 691). The digging of irrigation pits and mulching was proposed as a possible solution for drought-related seedling failures, resulting in a survival rate of about $70 \%$ in Southern Nigeria (ID: 860). Besides these environmental constraints, socioeconomic factors (here: fuelwood collection from recently planted trees) were another reason for the failure of tree plantings in Northern Nigeria (ID: 599 and 691). One respondent, therefore, proposed the use of alternative energy sources to reduce the pressure from fuelwood collection (ID: 599).

\subsubsection{Seedling Quality and Supply}

As indicated before, the lack of seedling adaptation to harsh site conditions and the limited supply of high-quality native seedlings were the main technical obstacles for regeneration success and productivity reported for several projects in the survey (IDs: 387, 897, 805, 599, and 794). Likewise, it was acknowledged that the production of sufficient numbers of native seedlings by local nurseries was an important contribution to project success in Tillaberi (Niger) and Amazonas (Venezuela) (IDs: 670 and 166). 
The demand for native seedlings is likely to increase with expanding forest adaptation and restoration activities and the strong focus on the use of local provenances of native species reported here (Figure 6). A lack of native tree seedlings from nurseries has resulted in the use of exotic trees in several cases: One respondent reported in the Philippines that this has led to the use of badly adapted exotic tree species and high mortality rates (ID: 897). In a case from Angola, the nurseries that usually focus on exotic plantation species promised to provide seedlings of native species but could not deliver sufficient quantities and qualities. As a result, respondents reported low survival rates and planting densities that were too low to form a stable forest. As mentioned before, this resulted in the need to plant non-native pines in critical areas along rivers (ID: 387). In a similar case from Vietnam described before, it was found that seedlings of native species were present in the understory of pine plantings and that this form of natural regeneration in plantings could be an option to counteract the limited supply of native seedlings (ID: 794).

\subsection{Local Communities in FLR}

The previous paragraphs already hinted at problems that were related to the neglect of the goals and perceived benefits of local land-users. In connection to this, various problems related to the broad topic of local community involvement in restoration projects were identified.

\subsubsection{Stakeholder and Community Involvement}

Most respondents agree that stakeholder participation was important for project success (Figure 7). In the AFM group, which was dominated by European projects that were often carried out by the forest service or other public bodies, stakeholder participation was regarded to be less important for success as compared to the FLR and combined measures groups (Figure 8). Hence, we found that, in the group of AFM projects, the stakeholder communities mostly did not participate in the project (Table 4). However, many projects from the FLR and combined measures groups also did not involve the stakeholder community (Table 4). Over two-thirds of the projects that were labeled by respondents as FLR or a combination of AFM/FLR and were carried out on state-owned and managed lands did not involve the stakeholder community (16 out of 21 cases with FLR/combined approaches on state-owned and managed lands). A similar top-down approach was reported for $45 \%$ of the projects on lands owned by the state where some ownership rights were exercised by local communities ( 9 out of 20 cases with the FLR/combined approach on state-owned lands where local communities exercised some ownership rights, e.g., access, management, and exclusion).

\section{Stakeholder participation \& success}

Level of agreement: "Participation of stakeholders

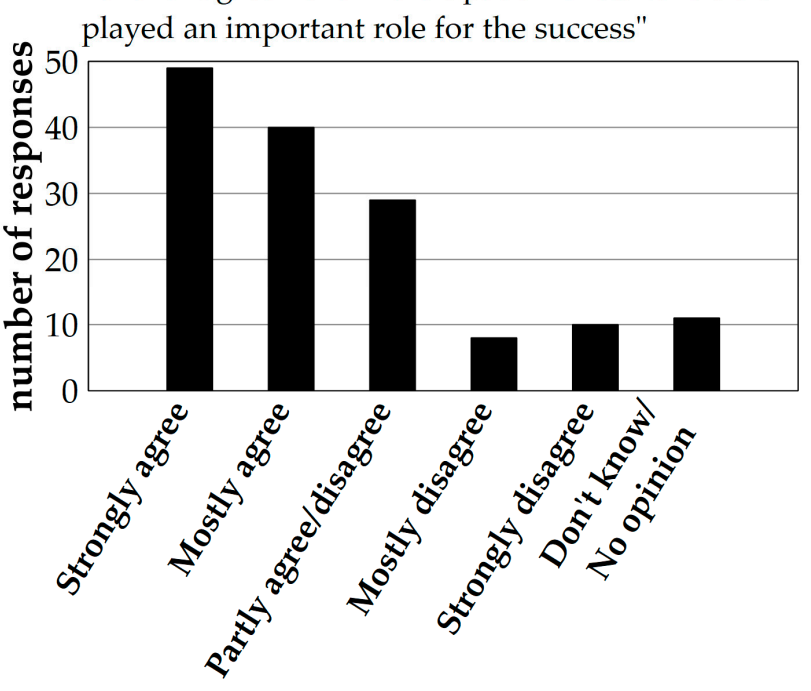

Figure 7. Role of stakeholder participation for project success. 


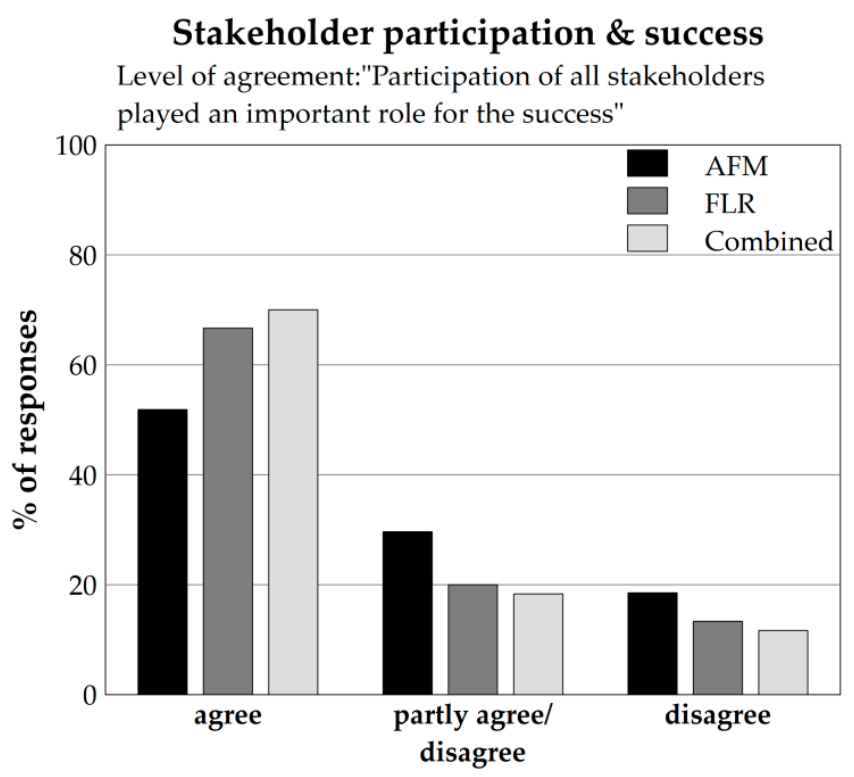

Figure 8. Level of agreement to the statement "The participation of all stakeholders was important for the success of the project" by types of projects.

Table 4. Participation of the local community in the projects by project type. NA corresponds to respondents that did not provide the type of measures that were implemented.

\begin{tabular}{cccc}
\hline \multirow{2}{*}{ Type of Measures } & \multicolumn{3}{c}{ Stakeholder Community Participated } \\
\cline { 2 - 4 } & Yes & No & Total \\
\hline AFM & 6 & 36 & 42 \\
FLR & 32 & 20 & 52 \\
Combination & 26 & 42 & 68 \\
NA & 1 & 2 & 3 \\
Total & 65 & 100 & 165 \\
\hline
\end{tabular}

From the provided comments, it became obvious that a lack of involvement of local communities as key stakeholders often contributed to the failure of respective projects. Several respondents highlighted that a lack of participation of local actors was a key factor for the failure of restoration projects (ID: $529,558,691,751,768,770$, and 897), while the early identification of stakeholders' issues (ID: 613) and community participation were identified as success factors for restoration projects (IDs: 554, 666, $668,669,693,713,740,762,768,770,786,808,813,816,893$, and 833). The already described cases from Malawi (ID 529), Ecuador (ID: 246), and Nigeria (IDs: 599 and 691) are not only examples of potentially conflicting goals but also examples of the lack of stakeholder involvement in the negotiation and definitions of these goals.

\subsubsection{Perceived Benefits for Land-Users}

The mentioned lack of involvement of local land-users appears to be linked to situations in which local communities did not perceive tangible benefits from the restoration activities. This was connected to a lack of support or a continuation of degrading activities.

In Malawi, the restoration land was perceived as unused (ID: 529), in Nigeria, the fruiting species that promised direct benefits were nurtured, while other young trees were used for fuelwood (IDs: 599 and 691), and, in Ecuador, the communities were not motivated to invest in degraded lands (ID: 246). In a case from the Caribbean region of Colombia, it was reported that the main reason for project failure was that it did not meet the expectations of local communities (ID: 805). From Hainan Island in China, it was reported that forests were converted to rubber, areca, and other crop tree plantations due to a lack of alternative livelihood sources. In contrast to this, it was reported from Niger and Uganda 
that restoration benefits in terms of improved livelihoods were felt quickly by local populations, which resulted in an adaption of the restoration practices beyond the initial project regions (ID: 808 and 833 ).

\subsubsection{Continued Degradation of Restoration Areas}

In connection to a lack of community involvement and perceived benefits or conflicting interests, several respondents reported the continued degradation of restoration sites (IDs: 344, 529, 558, 599, 691, 789, and 935).

In addition to this, forest protection may be hard to enforce: one respondent described a case from Cameroon where continued agricultural expansion and fuelwood extraction in a forest reserve led to restoration failure. This was associated with the reliance of local communities on forest exploitation, with increasing populations and a lack of trust and cooperation between authorities and the land-users. The respondent stressed that the enforcement of protection under these conditions was not possible (ID: 751). Another respondent also described problems with the enforcement of forest protection where land-users relied on forest utilization in Kwale, Kenya. As a consequence, the successful project included stakeholder training and the establishment of a sustainable management plan, as well as creating economic alternatives to forest use (ID: 816).

Several respondents reported that effective forest and resource protections against degrading activities were only achieved because local communities played an important role in the protection. Two respondents stated that restoration and conservation goals could only be reached after the community took a leading role in the management and protection of the resources after the state failed to reach the project goals in a top-down manner (IDs: 770, South Gondar and Ethiopia, and 693, Odisha and India). Similarly, local guards were hired to stop encroachment in the Desa'a Forest of Tigray (Ethiopia), where the local government and the community worked together to ensure the protection of the forest (ID: 786).

A possible explanation for the important role of local communities for resource protection is given by a case from Shinyanga, Tanzania. The respondent described that the successful protection of the restoration areas was only possible through local traditional institutions that were well-respected by the local communities and therefore capable of controlling access, enforcing protection, and resolving disputes effectively. The respondent stressed that the state government could not play this role (ID: 813).

\subsubsection{Institutional Challenges and Tenure}

Most of the survey respondents reported that state authorities and local stakeholders cooperated well in the respective projects (Figure 9). However, for some projects already described above, this was not the case. Besides, respondents described challenges related to the institutional support of restoration projects and tenure.

Respondents from Venezuela and Guatemala described the lack of long-term support of governmental institutions as an important challenge for the projects in terms of extension activities, training, research, and technical support (IDs:166 and 549). In a case from Central Kalimantan, Indonesia, there was a complete lack of support from governmental institutions and smallholders who depend and rely on technical and organizational management support by local NGOs (ID: 394). For the same project, the insecure land rights of the smallholders were identified as the main constraint for project success. In the already mentioned case from Tanzania, the lack of tenure security was described as a problem for the protection of restoration sites in some areas, and established ownership titles in other areas play a big role in restoration success (ID: 813). 


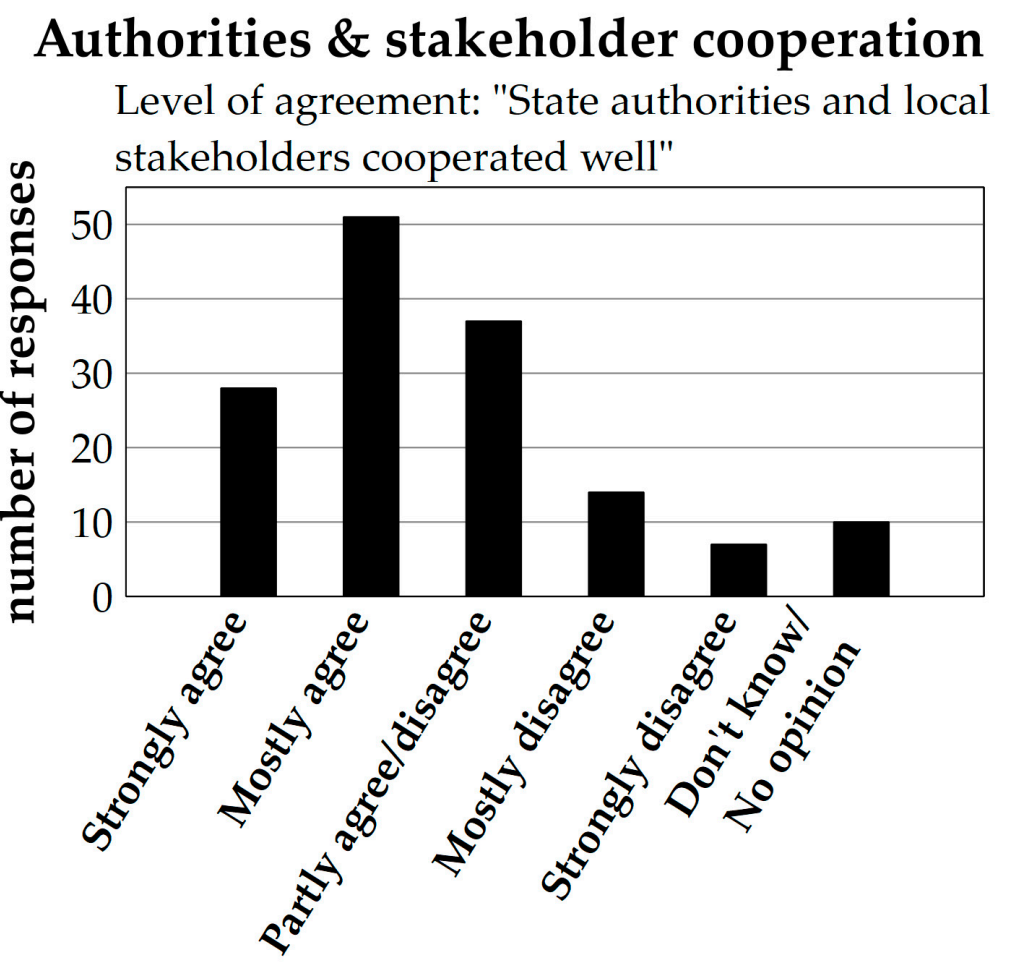

Figure 9. Cooperation of state authorities and local stakeholders.

\section{Discussion}

Our survey data suggests that the majority of the reported projects were successful in reaching management goals according to the perception of the respondents. However, it should be kept in mind that this result could have been influenced by the tendency towards reporting success rather than failure. Moreover, our results should be interpreted in consideration of the fact that the survey audience is dominated by highly educated individuals that are mostly employed in academics, the public sector, and NGOs. Therefore the audience can be classified as forest experts rather than foresters, which is not surprising considering our available channels of survey dissemination.

We have identified obstacles to forest restoration success in three broad thematic groups that are interrelated, with the overarching topic of stakeholder participation influencing many aspects of forest restoration. Here, we discuss our results in the same thematic groups used for the presentation of the results. We link our findings to the available literature to underline the relevance of the reported experiences outside of our limited sample of restoration projects. We then summarize available publications that propose solutions and tools with the potential to resolve the identified problems.

\subsection{Restoration Goals and Success}

Most respondents selected multiple priorities, and projects pursued socioeconomic and conservation goals concurrently (see Section 3.1). This relates to the FLR principles to restore multiple functionalities while addressing the concerns of various interest groups present in the landscape [11]. In this context, the negotiation, prioritization, and communication of goals in a participatory process are key for successful restoration planning [29,30]. Yet, our survey responses suggest that many projects have neglected this during project planning and implementation, so that local communities were frequently not actively involved in the project.

The case from Mzuzu, Malawi (ID 529) illustrated a lack of communication of project goals, which led to the intrusion of restoration sites that were perceived as unused land. A similar situation has been described in the literature [31], indicating that the perception of passive restoration areas as fallow lands could be common. 
Various failed projects described in Section 3.1.1 are characterized by a mismatch between the goals of project managers and local land-users, resulting in conflicting land-use activities. In connection to this, the benefits for local stakeholders were not defined or communicated, and the local land-users did not know or agree with the intentions behind the restoration activities. The examples from Hainan Island in China showed a slightly different perspective. Here, the local land-users tended to maximize their benefits by replacing natural forests with crop trees, since the main goal of the afforestation initiatives was a quantitative increase of forest cover. These area-related goals included plantations of such crop trees, thus creating a perverse incentive that conflicted with the goals of conservationists [24].

In the context of these conflicting goals, Sayer [30] states that restoration planning has to answer three important questions: "What should be restored?", "For whom should it be restored?", and "Why should it be restored?". Sayer [30] further notes that restoration projects frequently fail to address these questions. The described failed projects have in common that project initiators/managers have goals that define what should be restored. However, they at least partly disregard the goals and needs of local communities and, therefore, do not define sufficiently for whom and why the forests should be restored in terms of the benefits for local populations that go beyond the more general goals of forest restoration.

In some situations, the local community was not sufficiently motivated by the goals pursued by project management. Reaching a consensus and a shared vision among the different stakeholder groups with regards to restoration goals could enhance the needed community engagement in restoration activities [32]. Such a shared vision has to incorporate tangible benefits for local communities, as several cases described in Section 3.3.2 indicate.

The poor involvement of local communities in project planning, design, and implementation, which was an important reason for project failures in various cases reported here, has been acknowledged as a common problem for FLR [33]. An analysis of the socioeconomic reality of local communities and their motivations, expectations, pressures, and needs has been proposed to prevent such problems [33]. Resource users, as directly affected stakeholders, and other more indirect stakeholders (e.g., conservationists and development agencies), have to be incorporated into the negotiation, prioritization, and definition of goals as part of a multi-stakeholder participatory management process, as is widely acknowledged in the literature [9,30,34-37]. In practice, discussions with individual stakeholders, as well as between different interest groups, can help to identify the different goals and potential conflicts of resource users present in the landscape [9]. Despite this established need for a participatory process of negotiation and prioritization of restoration goals, it appears that many restoration projects still take a top-down approach that does not involve local communities in the definitions of the goals [38]. Since project managers might perceive this more complex process of goal definition as extra effort, it is important to understand that the added complexity is rather an opportunity than an impediment for their project [39].

After common goals are defined and put into action, changing or unexpected socioeconomic or biophysical conditions and technical limitations can lead to situations where the intended goals can only be met partly or the importance of the goals might change, as described by several respondents of our survey. Adapting to changing conditions by adjusting the restoration goals and practices in such situations was important, as strictly following the initial plans could have produced undesirable outcomes: The protection forests in Vietnam and Angola could have been understocked due to limited native seedling supplies, as reported in cases with similar problems, likely resulting in lower runoff reductions. The pulp plantations from Kenya and the Republic of the Congo could have been harvested to reduce economic losses without regard to their potential for fuelwood supply. The shelterbelt forest in Senegal could have been used excessively for fuelwood production, as reported from similar cases, resulting in a loss of sandstorm protection and fodder provision. Thus, adapting the initial goals and management practices to changing realities can be critical for ensuring the (partial) success of a project. The cases of spontaneous natural regeneration due to socioeconomic changes exemplify that 
changing conditions can also serve as new opportunities to adapt the broader land-use planning and management by including forest restoration goals.

In this context, the FLR principles acknowledge that restoration approaches should be adjusted to local ecological and socioeconomic conditions, values, and needs, and they should be adapted to changes in these conditions [11]. FLR, therefore, requires mechanisms that allow adjusting not only management practices but, also, project goals to changing conditions, unforeseen circumstances, and new challenges or opportunities. To this end, the integration of AFM in FLR [23], the application of adaptive management practices [40], and the project cycle management approach $[9,10,41,42]$ have been advocated in the literature. These approaches are characterized by the continuous monitoring of the restoration process and the provision of feedback, with the possibility to adapt planning and implementation.

In this regard, progress monitoring has been identified as a critical and essential part of restoration to assess the progress towards restoration goals and objectives, adapt restoration activities to changing conditions and unforeseen problems, and justify restoration efforts [41]. In practice, the establishment of a monitoring protocol has been reported to be one main factor for the success of the Atlantic Forest Restoration Pact (AFRP) in Brazil [43].

Project monitoring during the planning and implementation process can potentially counteract many of the identified problems. Monitoring during the restoration process can ensure that relevant stakeholders are involved, production requirements of nurseries can be met, drivers of degradation are addressed, and suitable silvicultural treatments are selected. This can enable adaptive management during implementation to identify problems in the early stages of the project. Then, outcomes of the implemented measures can be evaluated in light of the project goals. This can provide lessons about the applied restoration measures and inform funders and decision-makers about the progress towards the restoration goals.

However, several respondents of our survey have indicated a lack of monitoring activities, limited project timespans or temporary funding, narrowly defined indicators, and technical challenges that constitute an obstacle for monitoring and the application of adaptive management. It has been recognized that many restoration projects remain without sound monitoring, although the need for monitoring is well-established [38]. It has also been acknowledged that short project and funding durations can lead to a neglect of monitoring $[9,44]$.

Monitoring FLR has been given considerable attention in the literature: In ecological restoration, monitoring is often limited to indicators related to diversity, vegetation structure, and, in a few cases, ecological processes [45-47]. Monitoring in ecological restoration therefore often lacks the social and economic components required in FLR [48-51]. In response to this, a list of potential socioeconomic indicators, alongside guidance for the applications in FLR monitoring, has been proposed [49]. Various other publications provide indicators to monitor FLR progress [52-54]. Dey and Schweitzer [53] have developed a list of criteria for indicator selection to identify a small set of meaningful indicators. The process of indicator selection, monitoring design, and implementation should be based on a participatory process, similar to the definition of the restoration goals to which the monitoring relates $[41,53,54]$. To achieve this, the diagnostic for collaborative monitoring in FLR aids planners in designing and implementing a monitoring system by assessing factors that influence successful collaborative monitoring using a presence/absence scheme that can be applied throughout the different monitoring phases [55]. Applying collaborative monitoring in combination with capacity building to monitor the progress towards goals that are shared by local communities offers the opportunity to establish long-term monitoring and adaptive management beyond the limited project and funding periods noted before.

Despite this available guidance for FLR monitoring, the established need for a comprehensive, coherent, and practicable monitoring framework remains $[8,42,56]$. Moreover, many restoration practitioners do not perceive monitoring as an asset to assure project success but, rather, as an unnecessary expense [38]. Indeed, the development of comprehensive monitoring protocols requires 
considerable resources [57]. To assist FLR practitioners that lack these resources in the development of monitoring protocols, it has been recommended to develop a standardized FLR monitoring approach based on the existing protocols from Brazil's AFRP [58].

\subsection{Forest Regeneration}

In situations where forests have been converted to other land-uses or degraded so severely that, without intervention, the afflicted forests will continue to decline, the regeneration of trees is a major concern in forest restoration. Two regeneration strategies exist: passive restoration, which includes spontaneous and assisted natural regeneration (ANR), and active restoration with direct seeding or tree-planting approaches [59]. The effectiveness, potential benefits, and drawbacks of both strategies are a matter of debate [60-62]. While passive restoration approaches are most cost-effective for the restoration of extensive areas [63], they are not without costs and can face unforeseen expenses [31]. It is not our intention to resolve the passive vs. active restoration argument but present cases from our survey illustrating problems and opportunities for both approaches.

Three respondents reported cases where passive restoration through protection or socioeconomic changes and spontaneous natural regeneration was successful, while other projects failed due to environmental or anthropogenic constraints of natural regeneration. Environmental obstacles to natural regeneration were competing vegetation, browsing by wildlife, fire, and a high level of degradation and harsh environmental conditions.

The issue of competing vegetation is widespread in tropical regions [64] but, also, a major barrier in the boreal, temperate, and Mediterranean zones [65]. Various techniques to manage different forms of competing vegetation are applied throughout the world, with regional differences between preferred methods and varying effectiveness related to biophysical conditions and available resources [64-67]. Wildlife and fire managements were proposed by the respondents where these issues prevented natural regeneration. An extensive description of common threats to natural regeneration in the temperate zone and effective means to counteract them, including those mentioned in the survey, has recently been published [68].

Various projects describe the applications of such ANR practices to overcome barriers to natural regeneration, while some of them fail to address all possible obstacles. Shono [69] noted that ANR is a viable, yet underutilized method to overcome regeneration barriers and provides technical advice on ANR implementation. Holl and Aide [70] developed a conceptual framework that considers ecological and socioeconomic factors such as recovery rate, degradation levels, the surrounding land-use matrix, restoration goals, and available resources to aid in the selection of a suitable restoration approach. The framework raises the question of whether natural regeneration has the potential to facilitate forest recovery under the given circumstances or if intervention is needed and to what degree. This can ensure efficient resource allocation and increase restoration success [70].

Some conditions have to be met for ANR to be successful: not too-severe degradation or soil disturbance, the presence of some level of natural succession, a proximity to remnant forests, the presence of seed dispersers, the availability of labor, the willingness of local communities to support ANR, and the possibility to effectively protect restoration sites from the reoccurrence of degradation $[69,71]$. In particular, the problem of recurring degradation, a lack of natural seed sources, high levels of degradation, and missing community support have all been reported to limit ANR success by the respondents.

The required changes in land-use practices that facilitated natural regeneration in some cases presented here and not achieved in others are more complex than environmental factors that could be addressed by technical solutions. This was confirmed by Viani et al. [72], who observed a higher acceptance and easier implementation of forest conservation as compared to forest restoration, which required changes in land-use practices. The fact that land-use practices directly impact the success of passive restoration approaches underlines the urgent need for community support for successful ANR. 
Only active restoration measures were reported for projects in harsh environmental conditions. This is in-line with the current literature, which indicates that high levels of degradation, missing propagule sources, and harsh site conditions might necessitate more active approaches at higher costs $[73,74]$. However, tree planting does not, in every case, lead to successful forest regeneration, and the lack of adaptation of planting materials to harsh site conditions (in particular, drought), insufficient resources, or commitment to nurturing young seedlings and socioeconomic issues have prevented the success of plantings in several cases. These findings are also supported by the literature: a lack of adaptation of planting materials to site conditions [21,25,75] and a missing engagement of local communities in restoration activities [72,76], as well as socioeconomic issues causing continued or recurring forest degradation $[7,31,77,78]$, have been recognized as common problems.

Precipitation harvesting (planting pits) and mulching were proposed as a solution for drought-related seedling failures by a respondent in Southern Nigeria. This was supported by findings that suggested that half-moon-shaped planting pits were effective measures to increase the soil water content and facilitate the restoration success in Burkina Faso [79]. Coello et al. [80] provided a summary of such technical solutions to counteract periodical droughts and other techniques to overcome common restoration barriers in the context of FLR implementations in Southern Europe.

The socioeconomic issues that caused the failure of both passive restoration sites, as well as plantings, are directly connected to the topics of stakeholder involvement and project goals. The survey information presented here indicates that the lack of stakeholder involvement could impact regeneration success - in particular, through continued or recurring degradation or a lack of commitment to maintain restoration sites and nurture young seedlings. Planting agroforestry crops, NTFP species, and desired timber species among the naturally regenerated pioneer trees to strengthen and diversify income opportunities for local communities can enhance community support [69]. This is supported by the cases from Nigeria, where fruiting trees survived, while others were cut for fuelwood. Thus, approaches that enable local communities to utilize the restored forest and secure their interest in the resource are needed for the long-term success of any forest restoration approach [74]. Silvicultural considerations such as tree species selection, requirements vs. available resources for tending and watering, seedling and tree protection, etc. have to be addressed in consideration of the capacities and requirements of the local communities.

The major technical problem that was observed for active restoration approaches was related to the availability and quality of seedlings-in particular, concerning native tree species. The selection of seeds and seedlings that are well-adapted to current, as well as future, site conditions is crucial [59], and the use of maladapted and poor-quality plant materials may result in high mortality rates in the early stages of restoration projects [14], as observed by several respondents. Despite the importance of genetically diverse, high-quality planting materials for restoration success, a lack of genetic diversity, which is associated with low survival and growth rates, is widespread in FLR projects $[81,82]$. The limited supply of planting materials reported by survey respondents has also been acknowledged in the literature [81-84]. These limitations in nursery capacities have to be addressed through a communication process between project and nursery managers. A good example of this is the lack of native seedling supply that led to the shift from native to exotic species that are readily available in nurseries. Early communication with nurseries, keeping in mind the required time for propagation—especially with mast seeding trees, as recommended in the literature [81]—could prevent such situations. The potential role of exotic tree plantations as potential nurse crops to facilitate the regeneration of native trees, as described by one respondent and observed in various other tropical countries [85], could alleviate this problem to a limited degree. Another possible solution is to establish nurseries as part of the restoration project [14]. However, this will not be possible in all situations, and to meet global restoration targets, programs are needed to develop and support nurseries that are capable of meeting the increasing demand for high-quality planting materials [82].

In Chile, where the low quality and quantity of native seedlings constitutes a bottleneck for forest restoration, investments in the establishment of nurseries and the training of personnel, as well as the 
application of the target plant concept (TPC), have been recommended to counteract this limitation [83]. The TPC can be used to establish a partnership between the nurseries and restoration practitioners to evaluate what kind of plant materials, planting techniques, and planting times are most suitable for the particular project and the site to be planted [86]. Using the TPC can lead to increased survival and growth rates, while the site-specific monitoring of regeneration success allows the adaptability and improvement of production processes [87].

\subsection{Local Communities in FLR}

Throughout the comments of our respondents that describe problems and success factors for restoration implementation, the importance of local stakeholder involvement is a recurring theme. From the definition of goals and the implementation of silvicultural activities to the protection of restoration sites and their monitoring, the involvement of local communities can promote project success, whereas disregarding the people that actively use the land often leads to project failure.

In situations where the local communities perceived direct benefits from restoration, they contributed substantially to project success and played an important role in resource protection and management. This is in-line with research from the Philippines, which reports that the early engagement of local communities is triggered by financial incentives, while sustainable livelihoods and equitable benefits-sharing, among other things, contributes to long-term community support and restoration success [88]. Research from Southeast Asia has confirmed that communities involved in an ANR process play a vital role in the protection of forests from disturbances [89]. The need for stakeholder engagement in forest restoration was also observed in a case from Halimun-Salak (Indonesia) where the nonparticipation of communities raised conflicts and in Sungai Wain (Indonesia) where the collective action of the local people contributed to the success of the restoration initiatives and programs [37]. In-line with these, as well as our findings, the lack of stakeholder engagement is regularly reported to cause the failure of FLR projects, while landscape approaches, together with active participation, constitute the essential factors to ensure the success of restoration projects [16,90-92]. However, Elliott et al. [78] describe problems with encroachment, burning, and the conversion of restoration plots in Vietnam in a project that was initiated by the communities themselves. This indicates that community engagement and support are not necessarily the silver bullet against continued degradation driven by the local socioeconomic situation.

Institutional support is needed to strengthen the capacities of local communities and secure tenure rights, as reported by some of the respondents. This is needed to enable communities for long-term engagement with restoration projects and overall sustainable resource management [6,76]. Therefore, the local communities have to be considered as key stakeholders when it comes to the implementation of forest restoration.

It has been acknowledged that involving stakeholders in the various aspects of FLR implementation can lead to greater transparency and acceptance [93], social learning, and the effective consideration and understanding of stakeholder aspirations [94,95]. Stakeholder participation in FLR also acts as a pathway to understanding stakeholder values and motives and leads to the provision of appropriate multiple benefits from FLR [16,91]. Additionally, it aids in the recognition of trade-offs, which can enhance negotiations, reconciliation, and resilience, and as a consequence, it strengthens the sustainability of FLR.

Various tools have been developed to aid the process of stakeholder engagement, conflict resolution, and negotiations. These tools can be used during different project phases (i.e., visioning, conceptualizing, acting, and sustaining [10]). The Alignment, Interest, and Influence Matrix (AIIM) [96]; Network Mapping (Net-Map) [97]; and social mapping tools [98] can be used to identify existing stakeholder structures, key actors, channels of information and financial flow, and power relations. This enables for a better understanding of the needs and ambitions of various stakeholders, particularly those who live in the landscapes [99] that affect or are affected by the restoration projects [100]. This leads to the appropriate and strategic planning and implementation of FLR projects. However, 
in cases with complex decision-making among stakeholders, the Multi-Criteria Decision Analysis (MCDA) framework could be used to identify trade-offs, synergies, and define a course of action among stakeholders [101-103]. Additionally, spatial planning approaches can be used to visualize different land-use alternatives, work towards a consensus on a landscape scale [104], and enhance dialogue to determine acceptable sustainable solutions [100]. Various other tools, e.g., for the participatory monitoring and definition of common project goals have already been discussed in the previous sections.

In the past, top-down-organized, large-scale conservation, and carbon offset projects have often neglected to adapt management goals and practices to local socioeconomic realities and the need for participatory planning and benefit-sharing $[105,106]$. This led to displacement, poverty alleviation, loss of cultural identity, and various other problems $[105,106]$. While these issues are acknowledged in the conceptualization of FLR and the available literature and planning tools, the need for stakeholder participation and the recognition of stakeholder needs and values in practical restoration has especially been disregarded by many restoration practitioners. This entails the danger of project failure or, in extreme cases, even similar negative consequences for local populations, like those caused by problematic cases of forest conservation and carbon offset schemes (e.g., displacement and loss of livelihoods).

\section{Conclusions}

A summary of the main topics of this publication and the related obstacles and success factors as reported by the survey respondents is provided in Table 5. Our analysis has revealed several practical obstacles for forest restoration that require particular consideration, as they can lead to project failure. The obstacles reported here are not project-specific, since all problems included here have been described by more than one respondent and have also been reported in the literature. There was no single cause but several factors that contributed to project failure for many unsuccessful projects. Moreover, the problems were interrelated, and the participation of the local community, or the lack thereof, was an overarching topic found in the survey responses that connects to all other topics presented here.

Table 5. Overview of the topics presented in this publication, with the different categories to which the obstacles and problems of restoration, as well as success factors, that were reported by the survey participants correspond. ANR: assisted natural regeneration.

\begin{tabular}{|c|c|c|c|}
\hline Topic: & Category: & Observed Obstacles: & Success Factors: \\
\hline \multirow{4}{*}{$\begin{array}{l}\text { Restoration Goals } \\
\text { and Success }\end{array}$} & conflicting goals & $\begin{array}{l}\text { - lack of stakeholder involvement } \\
\text { - } \quad \text { lack of communication of goals } \\
\text { - } \quad \text { needs and benefits of local } \\
\text { communities not considered }\end{array}$ & $\begin{array}{l}\text { - } \quad \text { stakeholder involvement } \\
\text { consideration of stakeholder needs } \\
\text { and aspiration in the definition, } \\
\text { prioritization, and communication } \\
\text { of goals }\end{array}$ \\
\hline & measuring progress & $\begin{array}{ll}\text { - } & \text { short project and funding durations } \\
\text { - } & \text { technical difficulties } \\
\text { - } & \text { narrowly defined goals and indicators } \\
\text { - } & \text { neglect of monitoring as extra effort }\end{array}$ & $\begin{array}{l}\text { - } \quad \text { establishing monitoring protocols } \\
\text { selecting appropriate indicators that } \\
\text { reflect the multifunctional goals of } \\
\text { the project } \\
\text { - collaborative monitoring and } \\
\text { capacity building }\end{array}$ \\
\hline & $\begin{array}{l}\text { project funding } \\
\text { duration }\end{array}$ & $\begin{array}{l}\text { project and funding duration too short } \\
\text { for long-term restoration process } \\
\text { (limits monitoring and } \\
\text { adaptive management) }\end{array}$ & $\begin{array}{l}\text { - long-term funding } \\
\text { capacity building and buy-in of local } \\
\text { communities to enable for the } \\
\text { long-term management of } \\
\text { restored resources }\end{array}$ \\
\hline & $\begin{array}{l}\text { adapting } \\
\text { restoration } \\
\text { goals/measures }\end{array}$ & $\begin{array}{l}\text { - } \quad \text { changing or unexpected } \\
\text { socioeconomic or } \\
\text { environmental conditions } \\
\text { - technical limitations }\end{array}$ & $\begin{array}{l}\text { - } \quad \text { adapting goals and measures to } \\
\text { new conditions } \\
\text { - } \quad \text { progress monitoring in place }\end{array}$ \\
\hline
\end{tabular}


Table 5. Cont.

\begin{tabular}{|c|c|c|c|}
\hline Topic: & Category: & Observed Obstacles: & Success Factors: \\
\hline \multirow{4}{*}{$\begin{array}{c}\text { Forest } \\
\text { Regeneration }\end{array}$} & $\begin{array}{l}\text { natural } \\
\text { regeneration }\end{array}$ & $\begin{array}{l}\text { - environmental and anthropogenic } \\
\text { barriers to natural regeneration (e.g., } \\
\text { drought, competing vegetation, and } \\
\text { continued degradation) }\end{array}$ & $\begin{array}{ll}\text { - } & \text { suitable environmental and } \\
\text { socioeconomic conditions allow for } \\
\text { spontaneous natural regeneration } \\
\text { - } \quad \text { ANR to overcome barriers }\end{array}$ \\
\hline & $\begin{array}{l}\text { assisted natural } \\
\text { regeneration }\end{array}$ & $\begin{array}{ll}\text { - } & \text { recurring degradation } \\
\text { - } & \text { lack of community support } \\
\text { - } & \text { ANR sites perceived as barren lands } \\
\text { - } & \text { high levels of degradation and lack of } \\
\text { - } & \text { natural seed sources } \\
\text { lack of anticipation of } \\
\text { regeneration barriers }\end{array}$ & $\begin{array}{l}\text { - } \\
\text { - } \quad \text { changes in land-use practices } \\
\text { community engagement in the } \\
\text { protection of ANR sites } \\
\text { - } \quad \text { community buy-in } \\
\text { - capacity building to enable } \\
\text { land-users for ANR implementation }\end{array}$ \\
\hline & active restoration & $\begin{array}{l}\text { - } \\
\text { seedling failure (not adapted to } \\
\text { site conditions) } \\
\text { lack of capacities for watering } \\
\text { and tending } \\
\text { - continued degradation } \\
\text { (socioeconomic pressures) }\end{array}$ & $\begin{array}{l}\text { - } \quad \text { community engagement in } \\
\text { tending activities } \\
\text { - } \quad \text { community buy-in } \\
\text { site-adapted seedlings }\end{array}$ \\
\hline & $\begin{array}{l}\text { seedling quality } \\
\text { and supply }\end{array}$ & $\begin{array}{l}\text { - lack of seedling production in } \\
\text { particular native species } \\
\text { lack of quality of seedlings }\end{array}$ & $\begin{array}{l}\text { - } \quad \text { early communication between } \\
\text { restoration managers and nurseries } \\
\text { nursery capacities in-line with } \\
\text { restoration-related demands }\end{array}$ \\
\hline \multirow{4}{*}{$\begin{array}{l}\text { Local } \\
\text { Communities } \\
\text { in FLR }\end{array}$} & $\begin{array}{l}\text { stakeholder and } \\
\text { community } \\
\text { involvement }\end{array}$ & $\begin{array}{l}\text { - local communities not involved in } \\
\text { restoration projects }\end{array}$ & $\begin{array}{l}\text { community involvement and } \\
\text { consideration of needs and } \\
\text { aspirations throughout the } \\
\text { restoration process }\end{array}$ \\
\hline & $\begin{array}{l}\text { Perceived benefits } \\
\text { for land-users }\end{array}$ & $\begin{array}{l}\text { - no tangible benefits of the restoration } \\
\text { project perceived by the } \\
\text { local communities }\end{array}$ & $\begin{array}{l}\text { required benefits are defined by } \\
\text { local communities in the negotiation } \\
\text { of goals and materialize } \\
\text { during implementation }\end{array}$ \\
\hline & $\begin{array}{l}\text { continued } \\
\text { degradation of } \\
\text { restoration areas }\end{array}$ & $\begin{array}{l}\text { lack of community involvement, } \\
\text { perceived benefits, and conflicting } \\
\text { interests lead to } \\
\text { continued degradation } \\
\text { protection of restoration sites is hard } \\
\text { to enforce } \\
\text { local communities rely on degrading } \\
\text { land-uses for their livelihoods }\end{array}$ & $\begin{array}{l}\text { - } \quad \text { community involvement and } \\
\text { tangible benefits from restoration } \\
\text { the leading role of communities in } \\
\text { resource protection } \\
\text { and management } \\
\text { - economic alternatives to } \\
\text { degrading land-uses }\end{array}$ \\
\hline & $\begin{array}{l}\text { institutional } \\
\text { challenges and } \\
\text { tenure }\end{array}$ & $\begin{array}{l}\text { - lack of institutional support for } \\
\text { the restoration } \\
\text { - } \quad \text { tenure insecurity }\end{array}$ & $\begin{array}{l}\text { long-term institutional support } \\
\text { (e.g., technical- and } \\
\text { financial support) } \\
\text { secure tenure creates a long-term } \\
\text { perspective for land-users }\end{array}$ \\
\hline
\end{tabular}

Disregarding key principles of FLR [11], such as the engagement of key stakeholders in restoration, the provision of tangible benefits for the involved stakeholder groups, and monitoring for adaptive management, has been identified as problematic in various projects and has, in several instances, caused project failure. Other obstacles to forest restoration that were related to unfavorable biophysical conditions and technical problems could be addressed by various tools that are available in the published literature.

From the compiled obstacles, we can derive the following success factors and conclusions for restoration planning and implementation:

- The negotiation, definition, and communication of goals in a participatory process are crucial for successful restoration. We have highlighted that project failure was regularly linked to the fact that restoration goals were unknown to local communities or that there was a mismatch between the goals of the land-users and those of the project initiator/implementor. This often corresponds to a lack of perceived benefits by local communities. Various cases around the world reported here and in the available literature show that some forest restoration projects continue to ignore these crucial principles of FLR, resulting in failed projects and disappointed stakeholders. Such cases might also discourage potential FLR funders and policy-makers. 
- Various projects that were reported here demonstrated that local communities can play a central role in protecting and managing restoration areas and sometimes do so more efficiently than public bodies. Capacity-building and community buy-ins could be a solution to enable communities for the long-term sustainable and adaptive management and monitoring of the restored resources to overcome the problems of limited project and funding periods.

- Both passive, as well as active, restorations have their place in FLR, and none of these approaches is infallible. We need to choose the most suitable regeneration approaches and related silvicultural treatments and implement them under consideration of the site-specific environmental conditions and the socioeconomic situation of the landscape. Moreover, the various problems reported for forest regeneration emphasize the need for community support and capacity development in silvicultural and nursery practices. More site- or project-specific studies in various countries with forest restoration efforts are needed for a better understanding of practical restoration success at the intersection of environmental factors, socioeconomic conditions, and forest regeneration/silviculture.

- Stakeholder involvement not only in the planning of projects but, also, during implementation is crucial for restoration success. This can help to overcome various obstacles that were reported by survey participants, such as the protection of restoration sites, regeneration success and seedling survival, limited monitoring activities, and short project and funding periods. However, as mentioned above, too many projects from different parts of the world have disregarded the important role of the local community as key stakeholders.

- Considering the sample composition of our survey, the experiences presented here may be biased towards the perspectives of mostly forestry experts and so is much of the available literature on FLR implementation. Research is needed to better understand the perspectives of local communities on their experiences, goals, perceived success factors, and difficulties in practical forest restoration projects.

With the current attention for forest restoration and, in particular, the ambitious area-related goals of the Bonn Challenge, projects will likely emerge that are labeled as FLR, although they ignore key principles of FLR while also facing various technical challenges. The resulting problems and failed projects entail the danger of disappointed stakeholders at all levels and losing the momentum of the global FLR ambitions. By discussing such problematic cases, we hope to illustrate the existing gaps between the conceptualization and implementation of the global FLR ambitions and to provide guidance that can help to avoid costly repetitions of mistakes.

While we have presented and discussed some of the common problems that forest restoration projects face today and were able to propose existing tools and methods to address them, it is not possible to identify all the possible issues with our survey approach and within the scope of this publication. Major issues such as insecure tenure rights and institutional shortcomings were not discussed in detail, as they have to be addressed on the policy side rather than during project implementation and, therefore, go beyond the scope of this publication.

Supplementary Materials: The following are available online at http://www.mdpi.com/1999-4907/11/9/938/s1. The survey questions are available in PDF format. All survey responses that were quoted here using the respondent IDs are available in xlsx format.

Author Contributions: Conceptualization, M.H., J.A.S., P.E., M.K. and A.B.; data curation, M.H.; formal analysis, M.H.; investigation, M.H.; methodology, M.H.; project administration, A.B.; resources, A.B.; software, M.H.; supervision, A.B.; visualization, M.H.; writing — original draft, M.H. and V.A.; and writing-review and editing, M.H., V.A., J.A.S., P.E., M.K., and A.B. All authors have read and agreed to the published version of the manuscript.

Funding: This research received no external funding.

Acknowledgments: We thank all experts that participated in our survey for sharing their knowledge. We would further like to thank the staff of the IUFRO Headquarters in Vienna and all other colleagues who helped to disseminate the survey. This work is an activity of the IUFRO task forces Forest Adaptation and Restoration Under Global Change (https://www.iufro.org/science/task-forces/former-task-forces/forest-adaptation-restoration/) and Transforming Forest Landscapes for Future Climates and Human Well-Being (https://www.iufro.org/science/taskforces/transforming-forest-landscapes/). 
Conflicts of Interest: The authors declare no conflict of interest.

\section{References}

1. UNEA. New UN Decade on Ecosystem Restoration offers Unparalleled Opportunity for Job Creation, Food Security and Addressing Climate Change. Available online: https://www.unenvironment.org/news-andstories/press-release/new-un-decade-ecosystem-restoration-offers-unparalleled-opportunity (accessed on 13 January 2020).

2. Verdone, M.; Seidl, A. Time, space, place, and the Bonn Challenge global forest restoration target. Restor. Ecol. 2017, 25, 903-911. [CrossRef]

3. UNEP. Strategic Plan for Biodiversity 2011-2020: Provisional Technical Rationale, Possible Indicators and Suggested Milestones for the Aichi Biodiversity Targets. UNEP/CBD/COP/10/27/Add.1. Available online: https://www.cbd.int/doc/meetings/cop/cop-10/official/cop-10-27-add1-en.pdf (accessed on 13 January 2020).

4. Stanturf, J.A.; Madsen, P.; Sagheb-Talebi, K.; Hansen, O.K. Transformational restoration: Novel ecosystems in Denmark. Plant Biosyst. Int. J. Deal. All Asp. Plant Biol. 2018, 152, 536-546. [CrossRef]

5. Hobley, M. The Impacts of Degradation and Forest Loss on Human Well-Being and Its Social and Political Relevance for Restoration. In Forest Restoration in Landscapes; Mansourian, S., Vallauri, D., Eds.; Springer: New York, NY, USA, 2005; pp. 22-30, ISBN 978-0-387-29112-3.

6. Oviedo, G. Land Ownership and Forest Restoration. In Forest Restoration in Landscapes; Mansourian, S., Vallauri, D., Eds.; Springer: New York, NY, USA, 2005; pp. 84-93, ISBN 978-0-387-29112-3.

7. Robinson, D. Assessing and Addressing Threats in Restoration Programmes. In Forest Restoration in Landscapes; Mansourian, S., Vallauri, D., Eds.; Springer: New York, NY, USA, 2005; pp. 73-77, ISBN 978-0-387-29112-3.

8. Chazdon, R.L.; Guariguata, M.R. Decision Support Tools for Forest Landscape Restoration: Current Status and Future Outlook; Center for International Forestry Research: Bogor, Indonesia, 2018; ISBN 9786023870707.

9. Stanturf, J.A.; Mansourian, S.; Kleine, M. Implementing forest landscape restoration, a practitioner's guide. Int. Union For. Res. Organ. 2017, 2017, 1-128.

10. Stanturf, J.A.; Kleine, M.; Mansourian, S.; Parrotta, J.; Madsen, P.; Kant, P.; Burns, J.; Bolte, A. Implementing forest landscape restoration under the Bonn Challenge: A systematic approach. Ann. For. Sci. 2019, 76, 95. [CrossRef]

11. Besseau, P.; Graham, S.; Christophersen, T. Restoring Forests and Landscapes: The Key to a Sustainable Future; Global Partnership on Forest and Landscape Restoration; IUFRO: Vienna, Austria, 2018.

12. Chazdon, R.L.; Herbohn, J.; Mukul, S.A.; Gregorio, N.; Ota, L.; Harrison, R.D.; Durst, P.B.; Chaves, R.B.; Pasa, A.; Hallett, J.G.; et al. Manila Declaration on Forest and Landscape Restoration: Making It Happen. Forests 2020, 11, 685. [CrossRef]

13. UNEP. Decisions Adopted by the Conference of the Parties to the Convention on Biological Diversity at its Eleventh Meeting: Decision XI/16-Ecosystem Restoration. Available online: https://www.cbd.int/doc/ decisions/cop-11/cop-11-dec-16-en.pdf (accessed on 13 January 2020).

14. Thomas, E.; Jalonen, R.; Loo, J.; Bozzano, M. Avoiding failure in forest restoration: The importance of genetically diverse and site-matched germplasm. Unasylva 2015, 66, 29.

15. Kumar, C.; Begeladze, S.; Calmon, M.; Saint-Laurent, C. Enhancing Food Security through Forest Landscape Restoration: Lessons from Burkina Faso, Brazil, Guatemala, Viet Nam, Ghana, Ethiopia and Philippines; International Union for Conservation of Nature: Gland, Switzerland, 2015; ISBN 9782831717579.

16. Hanson, C.; Buckingham, K.; DeWitt, S.; Laestadius, L. The Restoration Diagnostic: A Method for Developing Forest Landscape Restoration Strategies by Rapidly Assessing the Status of Key Success Factors; International Union for Conservation of Nature: Gland, Switzerland, 2015.

17. GPFLR. Global Partnership on Forest and Landscape Restoration: Case Studies. Available online: https://www.forestlandscaperestoration.org/case-studies.html (accessed on 15 October 2019).

18. WRI. Forest Landscape Restoration Is More than Planting Trees: 3 Case Studies from the Western US. Available online: https://www.wri.org/blog/2015/07/forest-landscape-restoration-more-planting-trees-3case-studies-western-us (accessed on 15 May 2019).

19. Mwangi, E.; Evans, M. Communities Restoring Landscapes: Stories of Resilience and Success; Center for International Forestry Research: Bogor, Indonesia, 2018. 
20. IUFRO. Forest Landscape Restoration Implementation-Progress on the Ground: Scientific Snapshot Analysis Project. Available online: https://www.iufro.org/fr/science/special/spdc/netw/analysis/ (accessed on 22 December 2019).

21. Dudley, N.; Mansourian, S.; Vallauri, D. Forest Landscape Restoration in Context. In Forest Restoration in Landscapes; Mansourian, S., Vallauri, D., Eds.; Springer: New York, NY, USA, 2005; pp. 3-7, ISBN 978-0-387-29112-3.

22. IUCN. Making the Case for Forest Restoration: A Guide to Engaging Companies; International Union for Conservation of Nature: Gland, Switzerland, 2016.

23. Spathelf, P.; Stanturf, J.; Kleine, M.; Jandl, R.; Chiatante, D.; Bolte, A. Adaptive Measures: Integrating Adaptive Forest Management and Forest Landscape Restoration. Ann. For. Sci. 2018, 75, 55. [CrossRef]

24. Zhai, D.-L.; Xu, J.-C.; Dai, Z.-C.; Cannon, C.H.; Grumbine, R.E. Increasing tree cover while losing diverse natural forests in tropical Hainan, China. Reg. Environ. Chang. 2014, 14, 611-621. [CrossRef]

25. Cao, S.; Chen, L.; Yu, X. Impact of China's Grain for Green Project on the landscape of vulnerable arid and semi-arid agricultural regions: A case study in northern Shaanxi Province. J. Appl. Ecol. 2009, 46, 536-543. [CrossRef]

26. Lugo, A.E.; Helmer, E. Emerging forests on abandoned land: Puerto Rico's new forests. For. Ecol. Manag. 2004, 190, 145-161. [CrossRef]

27. Calvo-Alvarado, J.; McLennan, B.; Sánchez-Azofeifa, A.; Garvin, T. Deforestation and forest restoration in Guanacaste, Costa Rica: Putting conservation policies in context. For. Ecol. Manag. 2009, 258, 931-940. [CrossRef]

28. Birdsey, R.A.; Weaver, P.L. The Forest Resources of Puerto Rico; USDA: Washington, DC, USA, 1982.

29. Boedhihartono, A.K.; Sayer, J. Forest Landscape Restoration: Restoring What and for Whom? In Forest Landscape Restoration; Stanturf, J., Lamb, D., Madsen, P., Eds.; Springer: Dordrecht, The Netherlands, 2012; pp. 309-323, ISBN 978-94-007-5325-9.

30. Sayer, J. Goals and Targets of Forest Landscape Restoration. In Forest Restoration in Landscapes; Mansourian, S., Vallauri, D., Eds.; Springer: New York, NY, USA, 2005; pp. 101-108, ISBN 978-0-387-29112-3.

31. Zahawi, R.A.; Reid, J.L.; Holl, K.D. Hidden Costs of Passive Restoration. Restor Ecol. 2014, $22,284-287$. [CrossRef]

32. Vallauri, D.; Aronson, J.; Dudley, N. An Attempt to Develop a Framework for Restoration Planning. In Forest Restoration in Landscapes; Mansourian, S., Vallauri, D., Eds.; Springer: New York, NY, USA, 2005; pp. 65-70, ISBN 978-0-387-29112-3.

33. Sabogal, C.; Besacier, C.; McGuire, D. Forest and landscape restoration: Concepts, approaches and challenges for implementation. Unasylva 2015, 66, 3.

34. Sayer, J.; Kapos, V.; Mansourian, S.; Maginnis, S. Forest landscape restoration: The role of forest restoration in achieving multifunctional landscapes. In Proceedings of the XII World Forestry Congress, Quebec City, QC, Canada, 21-28 September 2003.

35. Le, H.D.; Smith, C.; Herbohn, J. What drives the success of reforestation projects in tropical developing countries? The case of the Philippines. Glob. Environ. Chang. 2014, 24, 334-348. [CrossRef]

36. Rietbergen-McCracken, J.; Maginnis, S.; Sarre, A. (Eds.) The Forest Landscape Restoration Handbook, 1st ed.; Earthscan: London, UK, 2007; ISBN 978-1-84407-369-6.

37. Van Oosten, C.; Gunarso, P.; Koesoetjahjo, I.; Wiersum, F. Governing Forest Landscape Restoration: Cases from Indonesia. Forests 2014, 5, 1143-1162. [CrossRef]

38. Coppus, R.; Romijn, J.E.; Méndez-Toribio, M.; Murcia, C.; Thomas, E.; Guariguata; Herold, M.; Verchot, L. What is out there? A typology of land restoration projects in Latin America and the Caribbean. Environ. Res. Commun. 2019, 1, 41004. [CrossRef]

39. Lamb, D.; Stanturf, J.; Madsen, P. What Is Forest Landscape Restoration? In Forest Landscape Restoration; Stanturf, J., Lamb, D., Madsen, P., Eds.; Springer: Dordrecht, The Netherlands, 2012; pp. 3-23, ISBN 978-94-007-5325-9.

40. Gilmour, D. Applying an adaptive management approach in FLR. In The Forest Landscape Restoration Handbook, 1st ed.; Rietbergen-McCracken, J., Maginnis, S., Sarre, A., Eds.; Earthscan: London, UK, 2007; pp. 43-52, ISBN 978-1-84407-369-6. 
41. Vallauri, D.; Aronson, J.; Dudley, N.; Vallejo, R. Monitoring and Evaluating Forest Restoration Success. In Forest Restoration in Landscapes; Mansourian, S., Vallauri, D., Eds.; Springer: New York, NY, USA, 2005; pp. 150-158, ISBN 978-0-387-29112-3.

42. O'Connor, S.; Salafsky, N.; Salzer, D. Monitoring Forest Restoration Projects in the Context of an Adaptive Management Cycle. In Forest Restoration in Landscapes: Beyond Planting Trees; Mansourian, S., Vallauri, D., Dudley, N., Eds.; Springer: New York, NY, USA, 2005; pp. 145-149, ISBN 978-0-387-29112-3.

43. Crouzeilles, R.; Santiami, E.; Rosa, M.; Pugliese, L.; Brancalion, P.H.S.; Rodrigues, R.R.; Metzger, J.P.; Calmon, M.; Scaramuzza, C.A.d.M.; Matsumoto, M.H.; et al. There is hope for achieving ambitious Atlantic Forest restoration commitments. Perspect. Ecol. Conserv. 2019, 17, 80-83. [CrossRef]

44. Sayer, J.A.; Margules, C.; Boedhihartono, A.K.; Sunderland, T.; Langston, J.D.; Reed, J.; Riggs, R.; Buck, L.E.; Campbell, B.M.; Kusters, K.; et al. Measuring the effectiveness of landscape approaches to conservation and development. Sustain. Sci. 2017, 12, 465-476. [CrossRef]

45. Jones, H.P.; Schmitz, O.J. Rapid recovery of damaged ecosystems. PLoS ONE 2009, 4, e5653. [CrossRef] [PubMed]

46. Crouzeilles, R.; Curran, M.; Ferreira, M.S.; Lindenmayer, D.B.; Grelle, C.E.V.; Rey Benayas, J.M. A global meta-analysis on the ecological drivers of forest restoration success. Nat. Commun. 2016, 7, 11666. [CrossRef] [PubMed]

47. Ruiz-Jaen, M.C.; Mitchell Aide, T. Restoration Success: How Is It Being Measured? Restor. Ecol. 2005, 13, 569-577. [CrossRef]

48. Aronson, J.; Blignaut, J.N.; Milton, S.J.; Le Maitre, D.; Esler, K.J.; Limouzin, A.; Fontaine, C.; de Wit, M.P.; Mugido, W.; Prinsloo, P.; et al. Are Socioeconomic Benefits of Restoration Adequately Quantified? A Meta-analysis of Recent Papers (2000-2008) in Restoration Ecology and 12 Other Scientific Journals. Restor. Ecol. 2010, 18, 143-154. [CrossRef]

49. Egan, A.; Estrada, V. Socio-Economic Indicators for Forest Restoration Projects. Ecol. Rest. 2013, 31, $302-316$. [CrossRef]

50. Wortley, L.; Hero, J.-M.; Howes, M. Evaluating Ecological Restoration Success: A Review of the Literature. Restor. Ecol. 2013, 21, 537-543. [CrossRef]

51. Stanturf, J.A.; Palik, B.J.; Williams, M.I.; Dumroese, R.K.; Madsen, P. Forest Restoration Paradigms. J. Sustain. For. 2014, 33, S161-S194. [CrossRef]

52. Gasana, J. Monitoring and evaluating site-level impacts. In The Forest Landscape Restoration Handbook, 1st ed.; Rietbergen-McCracken, J., Maginnis, S., Sarre, A., Eds.; Earthscan: London, UK, 2007; ISBN 978-1-84407-369-6.

53. Dey, D.C.; Schweitzer, C.J. Restoration for the Future: Endpoints, Targets, and Indicators of Progress and Success. J. Sustain. For. 2014, 33, S43-S65. [CrossRef]

54. Dudley, N.; Bhagwat, S.A.; Harris, J.; Maginnis, S.; Moreno, J.G.; Mueller, G.M.; Oldfield, S.; Walters, G. Measuring progress in status of land under forest landscape restoration using abiotic and biotic indicators. Restor. Ecol. 2018, 26, 5-12. [CrossRef]

55. Evans, K.; Guariguata, M.R. A Diagnostic for Collaborative Monitoring in Forest Landscape Restoration; Center for International Forestry Research: Bogor, Indonesia, 2019; ISBN 9786023870882.

56. Mansourian, S.; Vallauri, D. Lessons Learnt from WWF's Worldwide Field Initiatives Aiming at Restoring Forest Landscapes; WWF: Marseille, France, 2012.

57. Pinto, S.; Melo, F.; Tabarelli, M.; Padovesi, A.; Mesquita, C.; de Mattos Scaramuzza, C.; Castro, P.; Carrascosa, H.; Calmon, M.; Rodrigues, R.; et al. Governing and Delivering a Biome-Wide Restoration Initiative: The Case of Atlantic Forest Restoration Pact in Brazil. Forests 2014, 5, 2212-2229. [CrossRef]

58. Viani, R.A.G.; Holl, K.D.; Padovezi, A.; Strassburg, B.B.N.; Farah, F.T.; Garcia, L.C.; Chaves, R.B.; Rodrigues, R.R.; Brancalion, P.H.S. Protocol for Monitoring Tropical Forest Restoration. Trop. Conserv. Sci. 2017, 10, 194008291769726. [CrossRef]

59. Stanturf, J.A.; Palik, B.J.; Dumroese, R.K. Contemporary forest restoration: A review emphasizing function. For. Ecol. Manag. 2014, 331, 292-323. [CrossRef]

60. Crouzeilles, R.; Ferreira, M.S.; Chazdon, R.L.; Lindenmayer, D.B.; Sansevero, J.B.B.; Monteiro, L.; Iribarrem, A.; Latawiec, A.E.; Strassburg, B.B.N. Ecological restoration success is higher for natural regeneration than for active restoration in tropical forests. Sci. Adv. 2017, 3, e1701345. [CrossRef] [PubMed] 
61. Meli, P.; Holl, K.D.; Rey Benayas, J.M.; Jones, H.P.; Jones, P.C.; Montoya, D.; Moreno Mateos, D. A global review of past land use, climate, and active vs. passive restoration effects on forest recovery. PLoS ONE 2017, 12, e0171368. [CrossRef] [PubMed]

62. Reid, J.L.; Fagan, M.E.; Zahawi, R.A. Positive site selection bias in meta-analyses comparing natural regeneration to active forest restoration. Sci. Adv. 2018, 4, eaas9143. [CrossRef]

63. Lamb, D. Large-Scale Forest Restoration; Routledge: Abingdon, UK, 2014; ISBN 9780203071649.

64. Friday, K.S.; Drilling, M.E.; Garrity, D.P. Imperata Grassland Rehabilitation Using Agroforestry and Assisted Natural Regeneration; Southeast Asian Regional Research Programme; International Centre for Research in Agroforestry: Bogor, Indonesia, 1999; ISBN 979-95537-0-9.

65. Willoughby, I.; Balandier, P.; Bentsen, N.S.; Mac Carthy, N.; Claridge, J. Forest Vegetation Management in Europe: Current Practice and Future Requirements; European Co-operation in Science and Technology (COST): Brussels, Belgium, 2009.

66. Ammer, C.; Balandier, P.; Bentsen, N.S.; Coll, L.; Löf, M. Forest vegetation management under debate: An introduction. Eur. J. For. Res. 2011, 130, 1-5. [CrossRef]

67. Löf, M.; Rydberg, D.; Bolte, A. Mounding site preparation for forest restoration: Survival and short term growth response in Quercus robur L. seedlings. For. Ecol. Manag. 2006, 232, 19-25. [CrossRef]

68. Dey, D.C.; Knapp, B.O.; Battaglia, M.A.; Deal, R.L.; Hart, J.L.; O’Hara, K.L.; Schweitzer, C.J.; Schuler, T.M. Barriers to natural regeneration in temperate forests across the USA. New For. 2019, 50, 11-40. [CrossRef]

69. Shono, K.; Cadaweng, E.A.; Durst, P.B. Application of Assisted Natural Regeneration to Restore Degraded Tropical Forestlands. Restor. Ecol. 2007, 15, 620-626. [CrossRef]

70. Holl, K.D.; Aide, T.M. When and where to actively restore ecosystems? For. Ecol. Manag. 2011, 261, 1558-1563. [CrossRef]

71. Chazdon, R.L.; Guariguata, M.R. Natural regeneration as a tool for large-scale forest restoration in the tropics: Prospects and challenges. Biotropica 2016, 48, 716-730. [CrossRef]

72. Viani, R.A.G.; Bracale, H.; Taffarello, D. Lessons Learned from the Water Producer Project in the Atlantic Forest, Brazil. Forests 2019, 10, 1031. [CrossRef]

73. Jacobs, D.F.; Oliet, J.A.; Aronson, J.; Bolte, A.; Bullock, J.M.; Donoso, P.J.; Landhäusser, S.M.; Madsen, P.; Peng, S.; Rey-Benayas, J.M.; et al. Restoring forests: What constitutes success in the twenty-first century? New For. 2015, 46, 601-614. [CrossRef]

74. Löf, M.; Madsen, P.; Metslaid, M.; Witzell, J.; Jacobs, D.F. Restoring forests: Regeneration and ecosystem function for the future. New For. 2019, 50, 139-151. [CrossRef]

75. Gregorio, N.; Herbohn, J.; Harrison, S.; Pasa, A.; Ferraren, A. Regulating the Quality of Seedlings for Forest Restoration: Lessons from the National Greening Program in the Philippines. Small Scale For. 2017, 16, 83-102. [CrossRef]

76. Newton, A.C.; del Castillo, R.F.; Echeverría, C.; Geneletti, D.; González-Espinosa, M.; Malizia, L.R.; Premoli, A.C.; Rey Benayas, J.M.; Smith-Ramírez, C.; Williams-Linera, G. Forest Landscape Restoration in the Drylands of Latin America. Ecol. Soc. 2012, 17, 21. [CrossRef]

77. Rodríguez, J.C.; Sabogal, C. Restoring Degraded Forest Land with Native Tree Species: The Experience of "Bosques Amazónicos" in Ucayali, Peru. Forests 2019, 10, 851. [CrossRef]

78. Elliott, S.; Chairuangsri, S.; Kuaraksa, C.; Sangkum, S.; Sinhaseni, K.; Shannon, D.; Nippanon, P.; Manohan, B. Collaboration and Conflict-Developing Forest Restoration Techniques for Northern Thailand's Upper Watersheds Whilst Meeting the Needs of Science and Communities. Forests 2019, 10, 732. [CrossRef]

79. Kagambèga, F.W.; Thiombiano, A.; Traoré, S.; Zougmoré, R.; Boussim, J.I. Survival and growth responses of Jatropha curcas L. to three restoration techniques on degraded soils in Burkina Faso. Ann. For. Res. 2011, 54, 171-184.

80. Coello, J.; Cortina, J.; Valdecantos, A.; Varela, E. Forest landscape restoration experiences in southern Europe: Sustainable techniques for enhancing early tree performance. Unasylva 2015, 66, 82.

81. Jalonen, R.; Valette, M.; Boshier, D.; Duminil, J.; Thomas, E. Forest and landscape restoration severely constrained by a lack of attention to the quantity and quality of tree seed: Insights from a global survey. Conserv. Lett. 2018, 11, e12424. [CrossRef]

82. Haase, D.; Davis, A. Developing and supporting quality nursery facilities and staff are necessary to meet global forest and landscape restoration needs. Reforesta 2017, 4, 69-93. [CrossRef] 
83. Bannister, J.R.; Vargas-Gaete, R.; Ovalle, J.F.; Acevedo, M.; Fuentes-Ramirez, A.; Donoso, P.J.; Promis, A.; Smith-Ramírez, C. Major bottlenecks for the restoration of natural forests in Chile. Restor. Ecol. 2018, 26, 1039-1044. [CrossRef]

84. Cernansky, R. How to rebuild a forest. Nature 2018, 560, 542-544. [CrossRef]

85. Feyera, S.; Beck, E.; Lüttge, U. Exotic trees as nurse-trees for the regeneration of natural tropical forests. Trees 2002, 16, 245-249. [CrossRef]

86. Landis, T.D. The target plant concept. In Nursery Manual for Native Plants; Dumroese, R.K., Luna, T., Landis, T.D., Eds.; USDA: Washington, DC, USA, 2009; pp. 15-31.

87. Dumroese, K.; Landis, T.; Pinto, J.; Haase, D.; Wilkinson, K.; Davis, A. Meeting Forest Restoration Challenges: Using the Target Plant Concept. Reforesta 2016, 1, 37-52. [CrossRef]

88. Gregorio, N.; Herbohn, J.; Tripoli, R.; Pasa, A. A Local Initiative to Achieve Global Forest and Landscape Restoration Challenge-Lessons Learned from a Community-Based Forest Restoration Project in Biliran Province, Philippines. Forests 2020, 11, 475. [CrossRef]

89. Ganz, D.J.; Durst, P.B.; Dugan, P.C.; Mc Kenzie, P.J. Assisted natural regeneration: An overview. In Advancing Assisted Natural Regeneration (ANR) in Asia and the Pacific; Dugan, P.C., Durst, P.B., Ganz, D.J., McKenzie, P.J., Eds.; Food and Agriculture Organization of the United Nations; Regional Office for Asia and the Pacific: Bangkok, Thailand, 2003; ISBN 974-7946-49-1.

90. Reed, J.; van Vianen, J.; Deakin, E.L.; Barlow, J.; Sunderland, T. Integrated landscape approaches to managing social and environmental issues in the tropics: Learning from the past to guide the future. Glob. Chang. Biol. 2016, 22, 2540-2554. [CrossRef]

91. Mansourian, S.; Vallauri, D.; Dudley, N. Forest Restoration in Landscapes: Beyond Planting Trees; Springer: Berlin, Germany, 2005; ISBN 978-0-387-29112-3.

92. Le, H.D.; Smith, C.; Herbohn, J.; Harrison, S. More than just trees: Assessing reforestation success in tropical developing countries. J. Rural Stud. 2012, 28, 5-19. [CrossRef]

93. Crevier, L.P.; Parrott, L. Synergy between adaptive management and participatory modelling: The two processes as interconnected spirals. Ecol. Inform. 2019, 53, 100982. [CrossRef]

94. Sayer, J.; Sunderland, T.; Ghazoul, J.; Pfund, J.-L.; Sheil, D.; Meijaard, E.; Venter, M.; Boedhihartono, A.K.; Day, M.; Garcia, C.; et al. Ten principles for a landscape approach to reconciling agriculture, conservation, and other competing land uses. Proc. Natl. Acad. Sci. USA 2013, 110, 8349-8356. [CrossRef] [PubMed]

95. Metzger, J.P.; Esler, K.; Krug, C.; Arias, M.; Tambosi, L.; Crouzeilles, R.; Acosta, A.L.; Brancalion, P.H.S.; D'Albertas, F.; Duarte, G.T.; et al. Best practice for the use of scenarios for restoration planning. Curr. Opin. Environ. Sustain. 2017, 29, 14-25. [CrossRef]

96. Mendizabal, E. The alignment, interest and influence matrix (AIIM) guidance note. In ODI Manual/Toolkit; ODI: London, UK, 2010.

97. Schiffer, E.; Hauck, J. Net-Map: Collecting Social Network Data and Facilitating Network Learning through Participatory Influence Network Mapping. Field Methods 2010, 22, 231-249. [CrossRef]

98. Buckingham, K.; Ray, S.; Arakwiye, B.; Morales, A.G.; Singh, R.; Maneerattana, O.; Wicaksono, S.; Chrysolite, H.; Minnick, A.; Johnston, L. Mapping Social Landscapes: A Guide to Identifying Networks, Priorities, and Values of Restoration Actors. Available online: https://www.wri.org/publication/sociallandscapes (accessed on 10 October 2019).

99. Yang, A.; Bellwood-Howard, I.; Lippe, M. Social-ecological systems and forest landscape restoration. In Forest Landscape Restoration: Integrated Approaches for Effective Implementation; Mansourian, S., Parrotta, J., Eds.; Taylor \& Francis Group: Milton, ON, Cananda, 2018; pp. 65-82, ISBN 9781138084292.

100. Mansourian, S.; Parrotta, J.; Balaji, P.; Belwood-Howard, I.; Bhasme, S.; Bixler, R.P.; Boedhihartono, A.K.; Carmenta, R.; Jedd, T.; Jong, W.; et al. Putting The Pieces Together: Integration For Forest Landscape Restoration Implementation. Land Degrad. Dev. 2019, 1, 11. [CrossRef]

101. Belton, V.; Stewart, T.J. Multiple Criteria Decision Analysis: An Integrated Approach; Springer: Boston, MA, USA, 2002; ISBN 9781461355823.

102. Saarikoski, H.; Mustajoki, J.; Barton, D.N.; Geneletti, D.; Langemeyer, J.; Gomez-Baggethun, E.; Marttunen, M.; Antunes, P.; Keune, H.; Santos, R. Multi-Criteria Decision Analysis and Cost-Benefit Analysis: Comparing alternative frameworks for integrated valuation of ecosystem services. Ecosyst. Serv. 2016, 22, 238-249. [CrossRef] 
103. Saarikoski, H.; Mustajoki, J.; Hjerppe, T.; Aapala, K. Participatory multi-criteria decision analysis in valuing peatland ecosystem services-Trade-offs related to peat extraction vs. pristine peatlands in Southern Finland. Ecol. Econ. 2019, 162, 17-28. [CrossRef]

104. Sayer, J.; Boedhihartono, A.K. Integrated landscape approaches to forest restoration. In Forest Landscape Restoration: Integrated Approaches for Effective Implementation; Mansourian, S., Parrotta, J., Eds.; Taylor \& Francis Group: Milton, ON, CA, 2018; ISBN 9781138084292.

105. Adams, W.M.; Hutton, J. People, Parks and Poverty: Political Ecology and Biodiversity Conservation. Conserv. Soc. 2007, 5, 147.

106. Fairhead, J.; Leach, M.; Scoones, I. Green Grabbing: A new appropriation of nature? J. Peasant Stud. 2012, 39, 237-261. [CrossRef]

(C) 2020 by the authors. Licensee MDPI, Basel, Switzerland. This article is an open access article distributed under the terms and conditions of the Creative Commons Attribution (CC BY) license (http://creativecommons.org/licenses/by/4.0/). 